This item was submitted to Loughborough's Research Repository by the author.

Items in Figshare are protected by copyright, with all rights reserved, unless otherwise indicated.

\title{
Making rounds: the routine work of the teacher during collaborative learning with computers
}

PLEASE CITE THE PUBLISHED VERSION

http://dx.doi.org/10.1007/s11412-011-9134-8

\section{PUBLISHER}

Springer Verlag () International Society of the Learning Sciences, Inc.

VERSION

AM (Accepted Manuscript)

LICENCE

CC BY-NC-ND 4.0

\section{REPOSITORY RECORD}

Greiffenhagen, Christian. 2019. "Making Rounds: The Routine Work of the Teacher During Collaborative Learning with Computers". figshare. https://hdl.handle.net/2134/13253. 
This item was submitted to Loughborough's Institutional Repository (https://dspace.lboro.ac.uk/) by the author and is made available under the following Creative Commons Licence conditions.

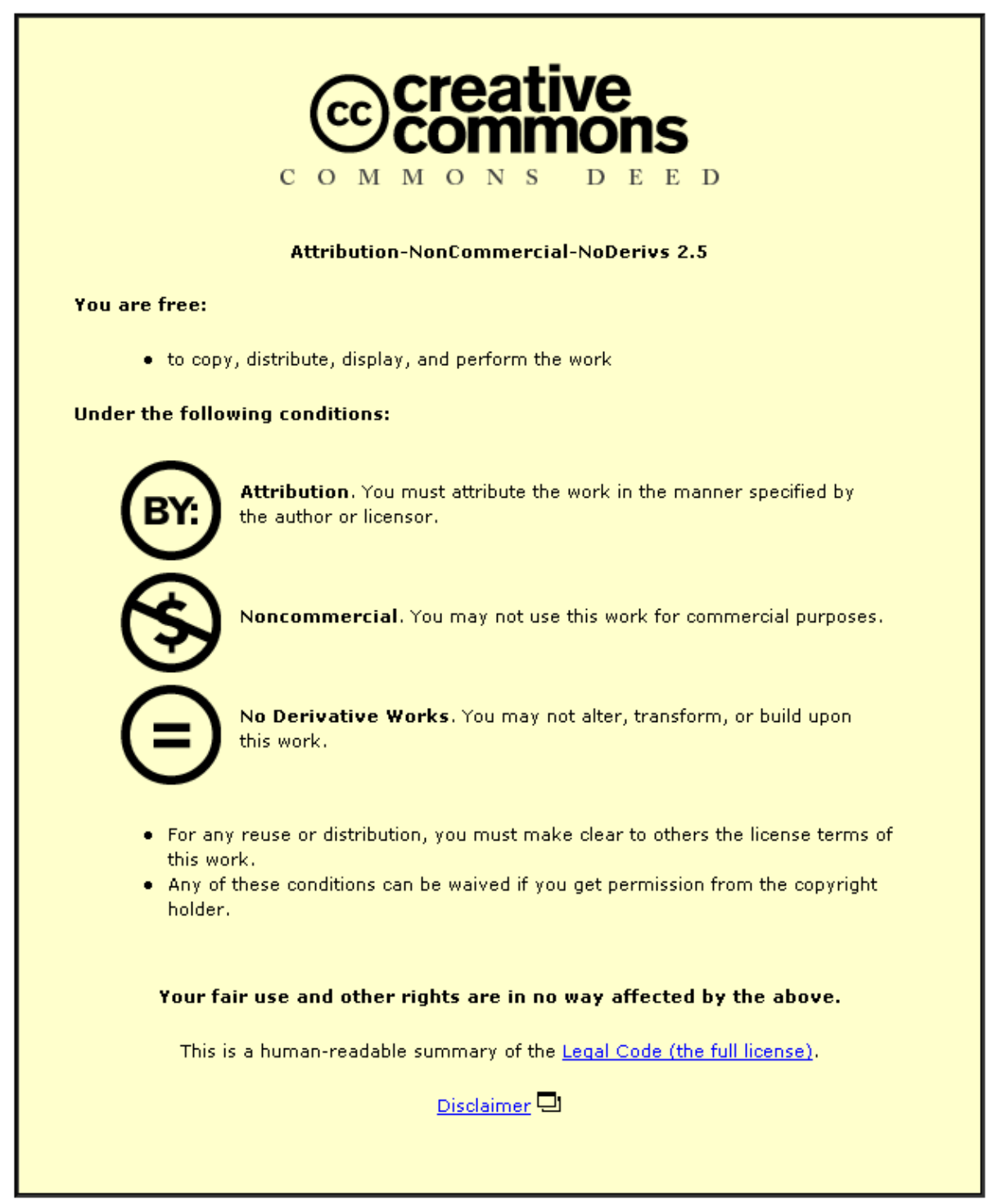

For the full text of this licence, please go to: http://creativecommons.org/licenses/by-nc-nd/2.5/ 


\title{
Making Rounds:
}

\section{the routine work of the teacher during collaborative learning with computers}

\author{
Christian Greiffenhagen
}

Version: September 14, 2011

\begin{abstract}
This paper provides a detailed analysis of the work of the teacher during collaborative learning activities. Whilst the importance of the teacher for the success of collaborative learning has frequently been recognized in the CSCL literature, there is nevertheless a curious absence of detailed studies that describe how the teacher intervenes in pupils' collaborative learning activities, which may be a reflection of the ambivalent status of teachers within a field that has tried to transfer authority from teachers to pupils. Through a close analysis of different types of teacher interventions into pupils working in pairs with a storyboarding tool, this paper argues, firstly, that concerns of classroom management and pedagogy are typically intertwined and, secondly, that although there may be tensions between the perspectives of teachers and pupils these do not take the form of antagonistic struggles. The paper concludes that it may be time to renew our interest in the work of teachers in the analysis of collaborative learning activities.
\end{abstract}

\section{Keywords}

teacher interventions; teacher's role; classroom management; scaffolding; collaborative learning; cooperative learning; ethnomethodology 


\section{Introduction}

This article deals with a familiar phenomenon of collaborative learning with computers ${ }^{1}$ : Once the teacher has set up a particular task (which is typically done by talking to the whole class) and pupils have started to work on this task alone or in pairs, the teacher does not sit back and relax at her or his desk, but rather 'makes rounds' (Mehan, 1989, p. 10) through the classroom to monitor, evaluate, and control what pupils are doing. Sorensen (2009, p. 155) provides a vivid description of this in the context of pupils working within an online 3D virtual environment ${ }^{2}$ :

The teacher [...] is rarely seated. He wanders around among children. He looks restless. His head and upper body move in staccato rhythms. He looks around uneasily. He bends down over a child, looks at his screen, and talks to him. After a while he gets up and goes to another child, just because she was in his way, or so it appears. He squats down and talks to her. He gets up and looks around. He walks to another computer, stands behind a child, and looks at the screen for two minutes. He points at something on the screen and talks to the child. He straightens his back. His eyes quickly scan the room. [...]

What interests Sorensen is the restlessness of the teacher in this situation, a restlessness which for her is the result of the changing nature of task: from a situation in which children are working on identical exercise books and going through the exercises in a sequential manner (thus giving the teacher an easy overview of what children have done and what they will do next) to a task which is more open-ended and has a less clear-cut sequential structure (thus making it much harder for

\footnotetext{
${ }^{1}$ There is a long-standing debate on the differences and similarities between 'collaborative', 'cooperative', or 'collective’ learning (see, e.g., Pea, 1996; Dillenbourg, 1999; Koschmann, 1999). I am using the term 'collaborative learning with computers' not to designate a particular pedagogical approach, but as a way to characterize situations in which the learning is organized through computer-mediated collaborative activities involving pairs or small groups of learners.

${ }^{2}$ In this situation the pupils are working on their own rather than in pairs.
}

Greiffenhagen, C. Making rounds: the routine work of the teacher during collaborative learning with computers. Forthcoming in International Journal of Computer-Supported Collaborative Learning (ijCSCL). 
the teacher to see what children have done and anticipate what they will do next). What interests me is less the restlessness than the organization of the work of teaching. My aim is to describe in greater detail what exactly a teacher does when he or she bends down to a child, looks at the screen, and talks to the child. In other words, I want to examine what, as the most practical matters in the world, teachers are doing during collaborative learning activities (not what they are supposed to do, but what they do do).

The analysis is based on video fragments from a project which examined the introduction of an educational technology into a secondary school in the UK. The software, called kar2ouche ${ }^{3}$, is an electronic storyboarding tool, which allows pupils to construct their own visual representations of Macbeth in a series of frames and which has been designed to be used by teachers as one of the variety of activities to engage pupils with Shakespeare as part of their English lessons. Both teachers involved in this study decided to have two pupils working together at the computer, a common arrangement for the use of instructional technologies in schools. In a previous article, I focussed on the way in which the teacher set up the storyboarding activity (Greiffenhagen, 2008), whereas in this paper I investigate the work of the teacher during the periods in which pupils were working with the storyboarding software.

Teachers could be said to have an ambivalent status in theories and studies of collaborative learning with computers (see, e.g., Koschmann, 1996; Koschmann et al. 2002; Stahl, 2006, 2009). On the one hand, a lot of technological innovation in school classrooms has been driven by the aim of transforming teaching and learning from 'teacher-led' whole-class instruction to more 'pupil-centred' practices (see, e.g., Cuban, 2001, p.14). This has been based on a new view of pupils who are no longer to be regarded as vessels to be filled with information imparted by the

\footnotetext{
${ }^{3}$ http://www.kar2ouche.com/
} 
teacher, but instead as active constructors of knowledge. Consequently, there have been attempts to transfer authority from teachers to pupils during learning activities (see Koschmann et al. 2000 on the resulting tensions for the teacher's role in problem-based learning).

Yet, on the other hand, it has always been recognized that teachers still play a crucial, albeit new, role during collaborative learning activities. Conceptions of the learning process rooted in notions such as 'scaffolding' and Vygotsky's 'zone of proximal development' (cf., Pea, 2004) acknowledge that the teacher, although no longer the 'sage on the stage', nevertheless has to act as a 'coach', 'facilitator', or 'guide' for pupils. Johnson and Johnson (1994 [1975], p. 114) describe this role in powerful terms for their conception of cooperative learning:

The teacher's job begins in earnest when the cooperative learning groups start working. Resist that urge to get a cup of coffee or to grade papers. Teachers observe the interaction among group members to assess students' academic progress and appropriate use of interpersonal and small-group skills. [...] Based on their observations, teachers can then intervene to improve students' academic learning or interpersonal and small-group skills.

Across the literature we find a tension where teachers have been conceptualised in both negative and positive terms: as authority figures that threaten to relieve pupils of self-directed opportunities to learn and as important facilitators that guide and stimulate pupils' learning activities.

The resulting tension could be one reason for the relative lack of empirical studies that investigate the work of the teacher during collaborative learning activities, a lack that has been noted in the literature. Gillies et al. (2008, p. 258), for example, state that "scant mention has been made of the role that teachers play in implementing cooperative pedagogy in their classrooms”; Urhahne et al. (2010, p. 237) complain that "research on information technology in education has given not enough attention to the role of the teacher, given the central part that the teacher plays in technology-enhanced classrooms"; while Webb et al. (2009, p. 49) observe that: 
Collaborative group work has great potential to promote student learning, and increasing evidence exists about the kinds of interaction among students that are necessary to achieve this potential. Less often studied is the role of the teacher in promoting effective group collaboration.

Of course, there are a variety of exceptions. There is an extensive literature that provides practical advice and guidelines for teachers on how to implement collaborative and cooperating learning activities, for example, how to structure such activities, how to group pupils, how to deal with diversity among pupils, how to give feedback, or how to engender a cooperative learning pedagogy in the classroom (see, e.g., Johnson and Johnson, 1994 [1975]; Cohen (1994 [1986]); Gillies et al., 2008; Urhahne et al., 2010).

There are also studies that have coded teachers' and pupils' discourse into a variety of categories to compare different learning situations and to assess the effects of teachers' interventions on pupils’ behaviour (e.g., Hertz-Lazarowitz and Shachar, 1990; Chiu, 2004; Dekker and ElshoutMohr, 2004; Gillies, 2004; Ding et al., 2007; Webb et al., 2009). For example, Hertz-Lazarowitz and Shachar (1990, p. 83) identify four types of practices - “(1) teacher praises and encourages pupils in relation to task performance; (2) teacher interacts with pupils in an intimate-egalitarian orientation; (3) teacher stages herself as a central figure in the classroom; (4) teacher interacts with pupils in a rigid authoritarian orientation” - and found that teachers' verbal behaviour differed significantly between traditional whole class instruction and interactions in group work. Chiu (2004) measured the length of teachers' interventions and recorded whether pupils were on or off task prior and subsequent to the intervention. Chiu found that pupils "were more likely to be on-task after speaking with the teacher than before doing so" and that "the beneficial effects of teacher interventions persisted for at least 5 minutes, but they faded over time” (p. 391). Webb et al. (2009) found that only 'probing' questions in contrast to other forms of interaction (such as acknowledgement of correct answers or issuing reminders) resulted in pupils "giving more detail about their problem-solving strategies, especially their producing correct/complete explanations of how to solve the problem” (p. 64). 
When we look at qualitative studies that aim to provide detailed accounts of the processes of collaborative learning, we find that they predominantly focus on what pupils are doing, but rarely describe the practices of the teacher during such activities. For example, Barnes and Todd (1977), in one of the earliest qualitative studies of small groups (although without computers), investigated the differences between whole class and small group behaviour and discussion among pupils. They give an illuminating account of the interaction among pupils, but say very little about what the teacher did during such group work, almost suggesting that the teacher played no role and never interacted with the groups. Heap (1989a,b), in one of the first videobased studies of collaborative writing with computers, provides a detailed description of the normative order at the computer, in particular, with respect to the different rights and responsibilities of pupils who acted as a 'writer' or as a 'helper'. However, Heap does not say whether, or in what ways, the teacher interacted with pupils while they collaborated (only that pupils gave their final stories to the teacher for evaluation). Roschelle (1992), in a pioneering and often cited study, investigated how pupils interacted with a computer software which graphically simulated the concepts of velocity and acceleration. On the basis of a detailed analysis of the interaction between two pupils, Roschelle provides a new conception of conceptual change to complement Piagetian and Vygotskian accounts. However, again, Roschelle is remarkably quiet about the role of the teacher (himself in this case) in engendering collaboration among pupils with the computer. Kelly et al. (2001) show how four groups of pupils differently interpreted the 'same' task. The authors mention that one of them acted as the physics teacher in the class, but say very little of what the teacher did once the task had been set up. For example, after an extended analysis of a discussion among the pupils, the authors state that "[a]t the end of the seventh discussion, when the group was unable to come to a common solution, the teacher intervened" (p. 164), but provide no account of how the teacher knew that he should intervene (was he summoned by the pupils? had he been monitoring what the pupils were doing?). Finally, Karlsson (2010) provides an extended analysis of how two pupils collaboratively interpret an computers. Forthcoming in International Journal of Computer-Supported Collaborative Learning (ijCSCL). 
animation of the mouldering process and formulate their written report. The analysis is based on very rich multimodal transcripts, which shows how much studies of collaborative learning have moved on since the early studies of, for example, Heap or Roschelle. As in those earlier studies, the focus is entirely on the pupils. The teacher is only mentioned once, when Karlsson remarks that the teacher did not approve of the final written account produced by pupils (p.174).

In sum, despite the acknowledged central role and responsibility of the teacher for implementing collaborative learning, there is an absence of the teacher in detailed accounts of collaborative learning using computers. The existing studies focus almost entirely on interactions among pupils and thus, at least implicitly, suggest that the teacher does not play a crucial role in setting up, monitoring, and shaping such activities in classroom contexts. There are only a few notable exceptions. In an early study, Mercer and Fisher (1992) focussed on the interventions of teacher in the computer-based activities of pupils, detailing the crucial role of the teacher in shaping and guiding these activities. Similarly, Roth (1995) investigated teacher-pupil (rather than pupil-pupil) interaction during collaborative learning with computers. More recently, Lindwall and Lymer (2008) have analysed an extended interchange between two pupils and an instructor who was summoned by the pupils when they were stuck and unsure how to proceed. The aim of this paper is to further detail the mundane work of the teacher during collaborative learning with computers.

\section{Methodology}

This study is in the tradition of what Macbeth (2003) has termed studies of 'naturally occurring discourse', which emerged in the 1970s under a variety of influences, including sociolinguistics (Cazden et al., 1972; Gumperz and Hymes, 1972), context analysis (McDermott et al., 1978), and, most pertinently for this paper, ethnomethodology (Garfinkel, 1967, 2002) and conversation analysis (Sacks, 1992; Schegloff, 2007). Using both audio- and video-recordings (cf., Koschmann et al., 2007; Heath et al, 2010), such studies have investigated a variety of taken-for-granted 
aspects of social interaction. Those aspects could be said to be the 'dark matter' of social interaction (Schegloff, 1996, p. 211; Lindwall and Lymer, 2008) and although in a certain sense 'uninteresting', especially to participants, they are nevertheless essential to accomplishing practical affairs. The challenge of such studies is not to uncover hidden phenomena that only become observable through new methodological tools or theoretical lenses, but to take interest in public organizations, and pay attention to the way in which unnoticed doings contribute to getting things done, something that Garfinkel has referred to as "getting the goldfish to become aware of the water" (cf., Watson, 2009, p. 103).

Within the educational literature, studies of naturally occurring discourse could be seen as an alternative to the predominant normative orientation of studies of classroom life. That is to say, many studies of educational settings rest on a view of what classroom interaction should be (in terms of the types of interaction or power relations that are educationally desirable or effective) and then - more often than not - go on to find that the reality of classrooms falls short. In contrast, studies of naturally occurring discourse try to set aside such normative expectations and instead aim to produce analytic descriptions of how classroom interaction is accomplished in orderly, collaboratively ways, by teachers and pupils.

Early studies influenced by ethnomethodology and conversation analysis focussed on traditional whole-class teaching (e.g., Payne, 1976; McHoul, 1978; Mehan, 1979; Payne and Cuff, 1982; Macbeth, 1990, 1991, 1992). In recent years, researchers have extended this perspective to a variety of educational and instructional contexts, for example, problem-based learning in medical education (Glenn et al., 1999), laboratory work in physics education (Ford, 1999; Lindwall and Lymer, 2008), the role of technology in architectural education (Lymer et al., 2009; Ivarsson, 2010), online learning environments (Garcia and Jacobs, 1999; Çakir et al., 2009), as well as postgraduate training in mathematics (Greiffenhagen and Sharrock, forthcoming). 
There are important respects in which the 'analytic mentality' (Schenkein, 1978) of ethnomethodolology and conversation analysis differs from the aims and methods of much research in CSCL, in particular, (1) the emphasis on analytic description rather than evaluation, (2) the focus on manifest rather than hidden aspects of interaction, (3) the dissolution rather than integration of supposedly different levels of social organisation.

Firstly, the policy of 'ethnomethodological indifference' (Garfinkel and Sacks, 1970, p. 345; Lindwall and Lymer, 2005) is in a certain sense against the whole point of CSCL. Simplifying greatly, it could be argued that one of the strongest motivations of much work in CSCL is the wish to improve current instructional practices through the design of new methods and innovative technologies (where that improvement can take a multitude of forms, from improving effectiveness to increasing the independence of pupils as learners). Consequently, there is an attendant emphasis on evaluation of both current and new practices. Ethnomethodology wants to step back and describe classroom practices without judging or evaluating them. Of course, there are various kinds of evaluations that are internal to the setting (e.g., teachers often evaluate pupils) and ethnomethodology takes an interest in explicating how such evaluations are accomplished. Ethnomethodology itself does not have its own (professional) standards for evaluating, for example, teachers.

Secondly, ethnomethodology and conversation analysis are concerned with the manifest character of social interaction. Garfinkel’s notion of 'accountability' was a way to emphasize that people do things in such a way that other people recognise them as what they are. The aim of the researcher then is to investigate how people accomplish this (e.g., what resources and methods they employ). This is stark contrast to the perhaps more common approach in the social sciences that supposes that doings are really otherwise than they initially appear and that their real character is 'hidden' (and therefore needs to be 'uncovered'). Macbeth (2003) expresses this 
focus on the public character of classrooms in his review of Hugh Mehan’s (1979) Learning Lessons (LL):

$L L$ was pointing to an orderliness of classroom lessons for which the participants themselves were actively engaged in producing their teaching and learning, its successes, failures, and relentless contingency, in full and public view, and moreover and especially, in the interactional detail of what indeed they were saying and doing. (p. 240; my emphasis)

In what sense could classroom lessons be said to be "in full and public view"? After all, other teachers rarely get to observe their colleagues, parents almost never get see what happens in classrooms 'to' their children, and classrooms are therefore often regarded as the 'private fiefdom' of teachers. However, "in full and public view” does not mean 'open to the public', but rather that any single action is done openly before an onlooking assembly of witnesses. That is to say, when a teacher asks a pupil a question, whether or not the pupil answers that question correctly will typically be evidenced by the teacher's reaction to everyone in the room. "In full and public view" then points to the fact that those elements relevant for the intelligibility of the current interaction are shown in the interaction (which is not to say that many aspects of what teachers and pupils do may not be visible in that way, for example, the teacher may have certain pedagogical aims in mind that he or she does not tell pupils).

Thirdly, ethnomethodology questions the widespread assumption that social organisation has to be described in terms of different levels (such as 'micro' and 'macro'), which have to be combined, integrated, or otherwise related by the researcher. Ethnomethodology does not deny the relevance of the sort of phenomena that are typically referred to by terms such as 'macro' or 'structures' (e.g., governmental policies or funding arrangements), but asks for demonstration of their witnessable relevance in the organisation of the occasion at hand (cf., Sharrock and Watson, 1988; Coulter, 2001; Greiffenhagen and Sharrock, 2008). Ethnomethodology does not disregard the fact that classroom activities are situated in schools, which are part of administrative districts, which are subject to policy arrangements, and so on. For ethnomethodology the challenge is to 
show whether and how these features are present and displayed in the ongoing production of a classroom lesson. Methodologically, this places the researcher in the same position as the participants in the classroom who have to figure out what is going on in the classroom from what is witnessable within the classroom. Finally, ethnomethodology insists that supposedly 'macro' phenomena such as school management or educational policy decision making are just other topics that could be studied in the same way.

So what contributions can ethnomethodology and conversation analysis make to the design of educational technologies? A good inspiration are the various 'workplace studies’ (e.g., Suchman, 1987; Button et al., 1993; Luff et al., 2000) that have focussed on the routine and 'uninteresting' features of the practices surrounding a variety of technologies (from photocopiers to traffic control rooms). Whatever the aims and motivations behind the introduction of technologies into the workplace (which are often high-minded indeed), it is still the case that these will have to be incorporated into existing practices 'on the ground'. As Heath et al. (1995, p. 147) point out, the failure of various technological systems "derives not so much from their technological limitations, but more from their insensitivity to the organisations of work and communication in real world environments". A good understanding of 'the ground' thus may be essential to the design of 'successful' technologies and make it possible "to avoid some of the pitfalls which frequently arise in the introduction of 'inappropriate' systems into real-world environments" (Heath and Luff, 1992, p. 92).

\section{The study}

This paper is based on a three-month observational study of how a storyboarding software was integrated into English lessons. The lessons observed were part of the preparation for the Shakespeare element of their Key Stage 3 National Tests in English (SATs). During the time of the study pupils spent the majority of their English lessons studying Macbeth through a variety of 
activities such as reading the play aloud, listening to audio-recordings, acting out particular scenes, and watching the play both on video and at the theatre. Having thus studied Macbeth for some weeks, working with the storyboarding tool became an additional activity for this class.

The storyboarding tool was designed to enable pupils to construct a visual representation of Shakespeare's Macbeth (see the interface in the appendix). Storyboarding is, of course, a wellknown technique for teaching Shakespeare (cf., Gibson, 1998, p.210). The new idea was to computerise this traditional technique in order to simplify the construction of frames, thereby making it more enjoyable for pupils (who would often have difficulty understanding Shakespeare, as well as find Shakespeare generally unappealing). In sum, the aim of the software was to facilitate creative learning, close engagement with the text, and also, at least implicitly, contribute to the preparation for the national exams.

We observed and video-recorded lessons from two English teachers of two different Year 9 classes (thirteen or fourteen year-old pupils). Both lessons in traditional classrooms and those in the computer suite were observed. Furthermore, we conducted several interviews with teachers and pupils. After each lesson in the computer suite, all the storyboards produced by the pupils were saved and collected. In total we observed nine lessons with the first teacher (seven in the computer suite) and thirteen with the second (eight in the computer suite). Figure 1 shows the setup of the two video cameras in the computer suite. The first camera was always focussed on a particular pair of pupils. The second camera was initially focused at the front (since the teacher was talking to the whole class) and in subsequent lessons focussed on a second pair of pupils. 

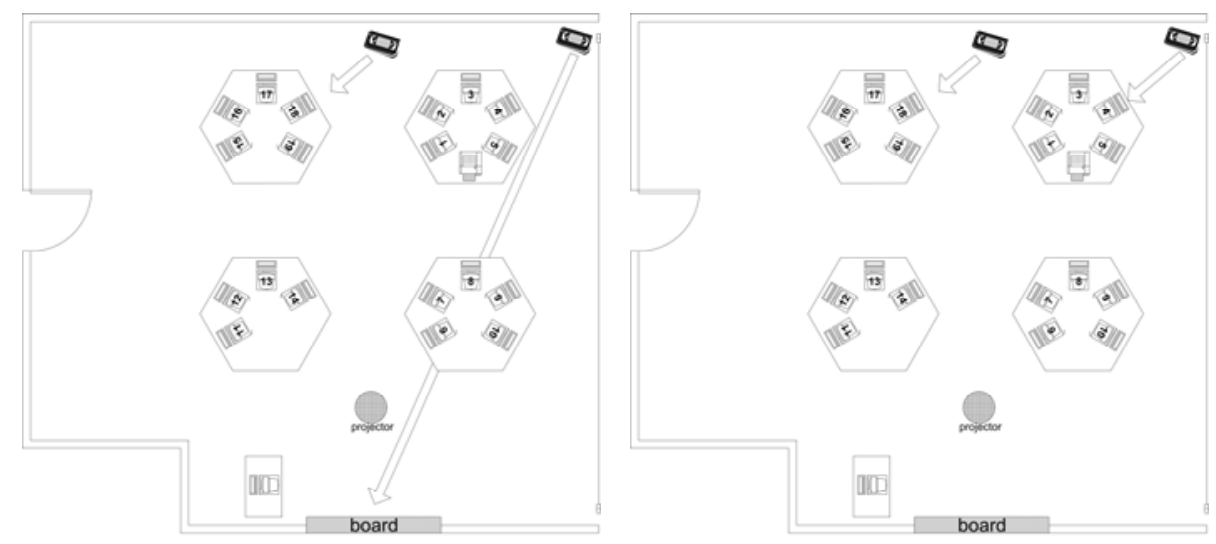

Figure 1: two different setups of the video cameras

For the purpose of this paper, I looked at all the lessons of one teacher, selecting instances in which the teacher interacted with the pupils. Since the focus is on the work of the teacher, the transcripts focus predominantly on what was said and only highlight particularly noteworthy features of the participants bodily conduct and the visual arrangements of the items on the screen (since we can understand, for example, that the teacher corrects a spelling mistake without close analysis of the teacher's body orientation or the exact configurations of the items on the screen). Elsewhere I have explored, for example, how pupils 'repair' items on the screen (Greiffenhagen and Watson, 2009), how both teacher and pupils point to specific places on the screen (Birmingham et al., 2002), or how pupils topicalise the placement of speech bubbles within a frame (Greiffenhagen, forthcoming).

\section{Analysis}

As already pointed out, the aim of this paper is to investigate the role of the teacher after she had set up the activity. Nevertheless, it is necessary to provide a brief summary of how the teacher introduced both the software and the task in the first lesson (for a detailed analysis see Greiffenhagen, 2008). The storyboarding tool was introduced thus: 


\section{Fragment 1 [Feb 16; first computer lesson]}

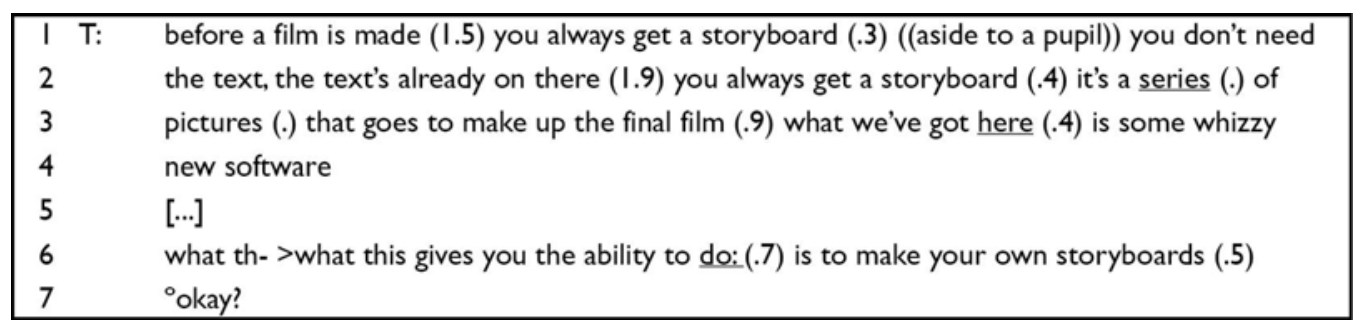

The teacher subsequently told pupils how to construct a frame (by inserting character, pictures, and backgrounds and changing the size, position, and pose of the characters), how to insert speech and thought bubbles (telling pupils that they should use the former for Shakespeare's original dialogue and the latter for their interpretation of the characters' thoughts), and how to use the caption box below the frame (instructing pupils to formulate their reasons or choices for constructing the frame in that particular way). The whole task was summarised at the beginning of the second lesson:

\section{Fragment 2 [Mar 2; second computer lesson]}

\begin{tabular}{|c|c|}
\hline $\mathrm{I} \mathrm{T}:$ & think about how you're going to break up this opening- >this opening part of this scene, how \\
\hline 2 & you're going to break it up (1.4) ${ }^{\circ}$ okay? (.) and start constructing your scenes (.6) this is the \\
\hline 3 & work you're gonna save and work on for the next week (I.4) so by this time next week (I.3) \\
\hline 4 & we're gonna have a fair interpretation of this scene from each of you $(I .0)$ any questions? (I.3) \\
\hline 5 & anybody not know what I want them to do? (.9) so you're gonna fill in- >put in your characters \\
\hline 6 & (.4) put in your speech- >choose a bit of speech from the text (.3) and put in the thought \\
\hline 7 & bubbles $($.$) and underneath say why you made the choices that you've made (1.2)^{\circ}$ alright? \\
\hline
\end{tabular}

The task as laid out here by the teacher engaged the pupils in a particular analysis of Shakespeare's text and suggests a four-step sequence: picture construction (scene, characters, and props), speech bubbles (for Shakespeare's text), thought bubbles (for their interpretation of that text), and finally the caption box (for their account of the whole frame). Pupils to a large extent followed this sequence, although - as we will see - they did not place equal emphasis on each of the four steps. 


\section{Ratifying}

Perhaps the simplest form of interaction between teacher and pupils consists of the teacher ratifying the work that pupils were doing or had done. For example, in Fragment 3, the teacher approaches behind two pupils, looks at the work on the screen, and then ratifies what they have done.

\section{Fragment 3 [Mar 6; fourth computer lesson]}

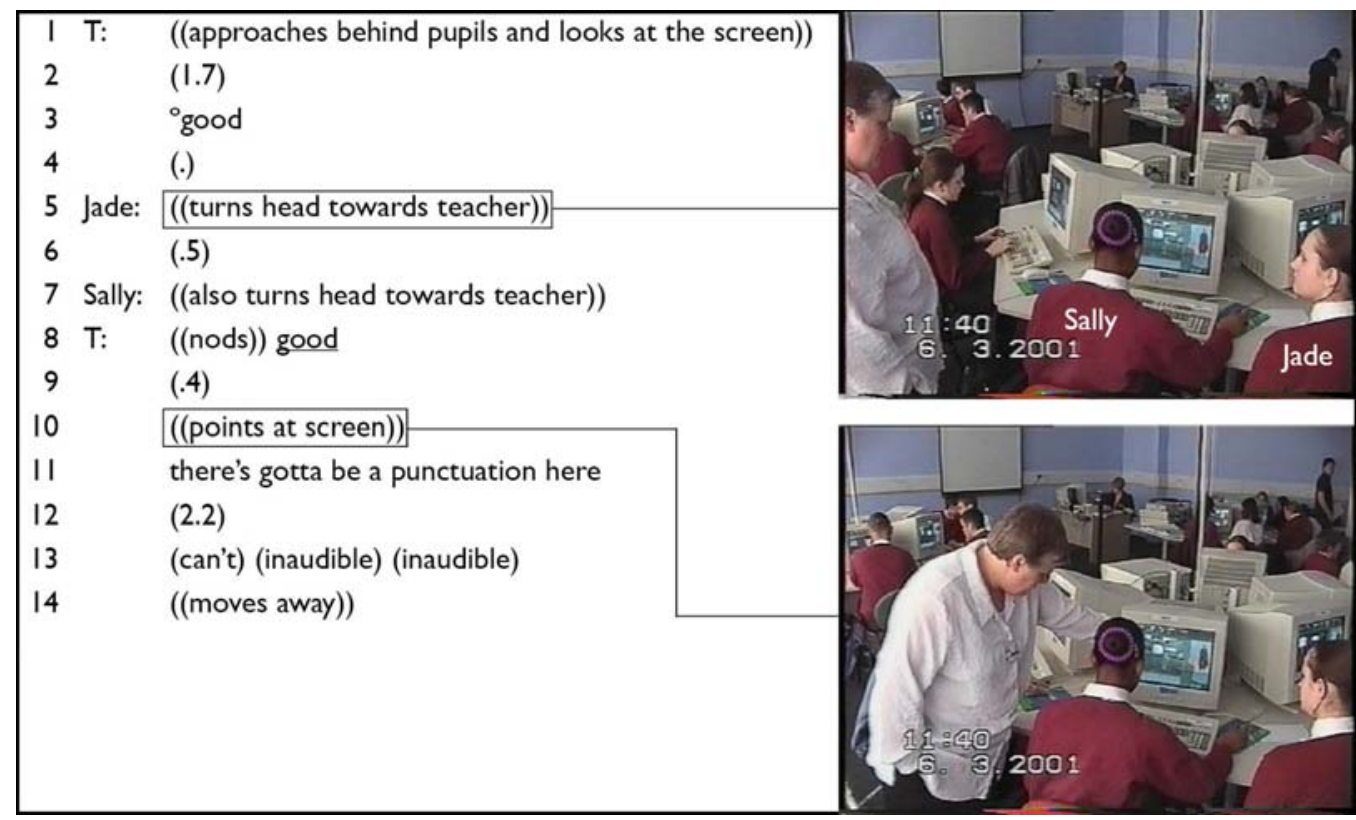

In this episode the teacher does little more than tell pupils that what they have done is satisfactory. Something that also has been described by Webb et al. (2006, p. 95):

In some visits with small groups, teachers confirmed the accuracy of students' answers or procedures (usually in response to a student request that a teacher check the group's work) and provided no further help [...]. In these similarly brief visits, teachers typically said little more than 'that's right'.

What is perhaps remarkable is how unremarkable this interaction between teacher and pupils is (by which I mean that both parties treat it as a familiar aspect of classroom lessons). The teacher clearly has the right (and responsibility) to evaluate pupils' work. In response to the teacher's computers. Forthcoming in International Journal of Computer-Supported Collaborative Learning (ijCSCL). 
initial utterance (“ogood”, line 3), both pupils turn around to look at the teacher (lines 5 and 7), thereby almost requiring the teacher to produce another turn (which she does in line 8). Pupils can thus expect that as part of her rounds the teacher will regularly stop and look at the work they have been doing.

What is noteworthy is that although the teacher accepts what the pupils are doing 'in general', she nevertheless points to missing punctuation (line 11). This might seem rather 'picky': the pupils are constructing a storyboarding of a scene from Shakespeare's Macbeth - how important could some missing punctuation be? However, the teacher's comment points to an orientation to the fact that the current storyboarding activity is part of an English lesson (i.e., not an IT or art lesson). Hence, correct punctuation is an important aspect of the activity, as is, of course, correct spelling:

\section{Fragment 4 [Mar 12; sixth computer lesson]}

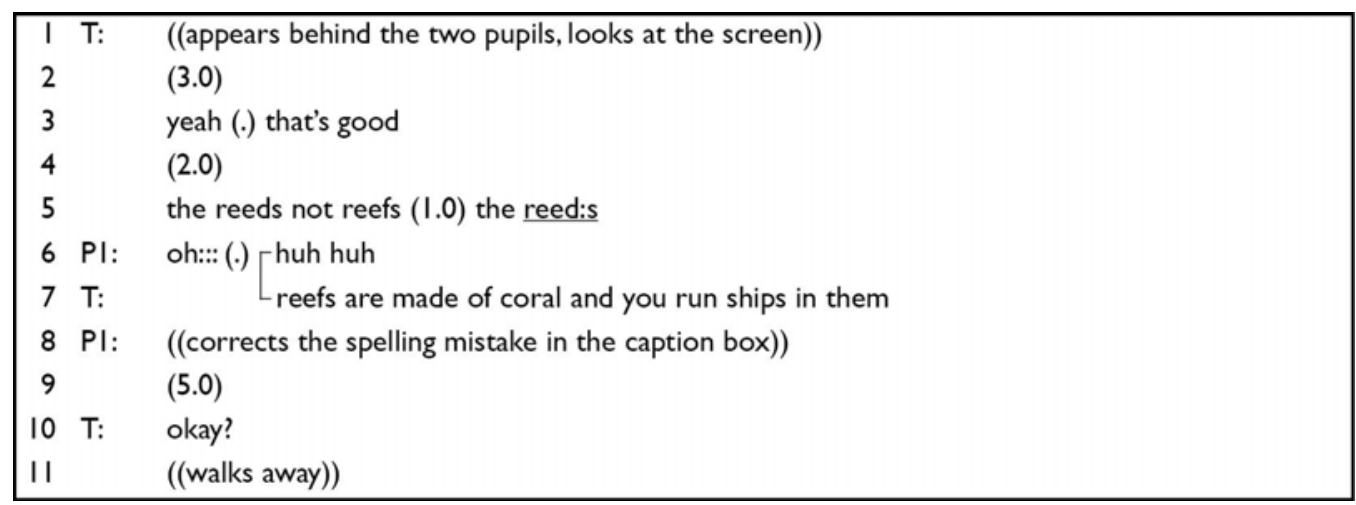

This fragment resembles the previous one: the teacher ratifies what the pupils are doing (line 3), but points out a spelling mistake (line 5), which one of the pupils corrects (line 8). Again, the whole episode is treated by both parties as unremarkable.

The emphasis on spelling and punctuation, apart from exhibiting the fact that the storyboard activity was part of an English lesson, can also be seen as reminding pupils - indirectly - that the current activity was not an end in itself, but part of the preparation for the national examinations computers. Forthcoming in International Journal of Computer-Supported Collaborative Learning (ijCSCL). 
(SATs) at the end of the year. As the other teacher in the study once reminded the class: "In your SATs, you will lose marks if you are not spelling words correctly.” Teachers recurrently sought to tie the activity to the pupils' performance on later standardised exams, which were a 'scenic feature' of the activity (see below).

\section{Reminding}

Of course, not everything the pupils did was to the teacher's satisfaction. Consequently, the teacher would frequently remind pupils of aspects of the task they had not (yet) done. In the following fragment, the teacher approaches a pupil working on her own:

\section{Fragment 5 [Mar 2; second computer lesson]}

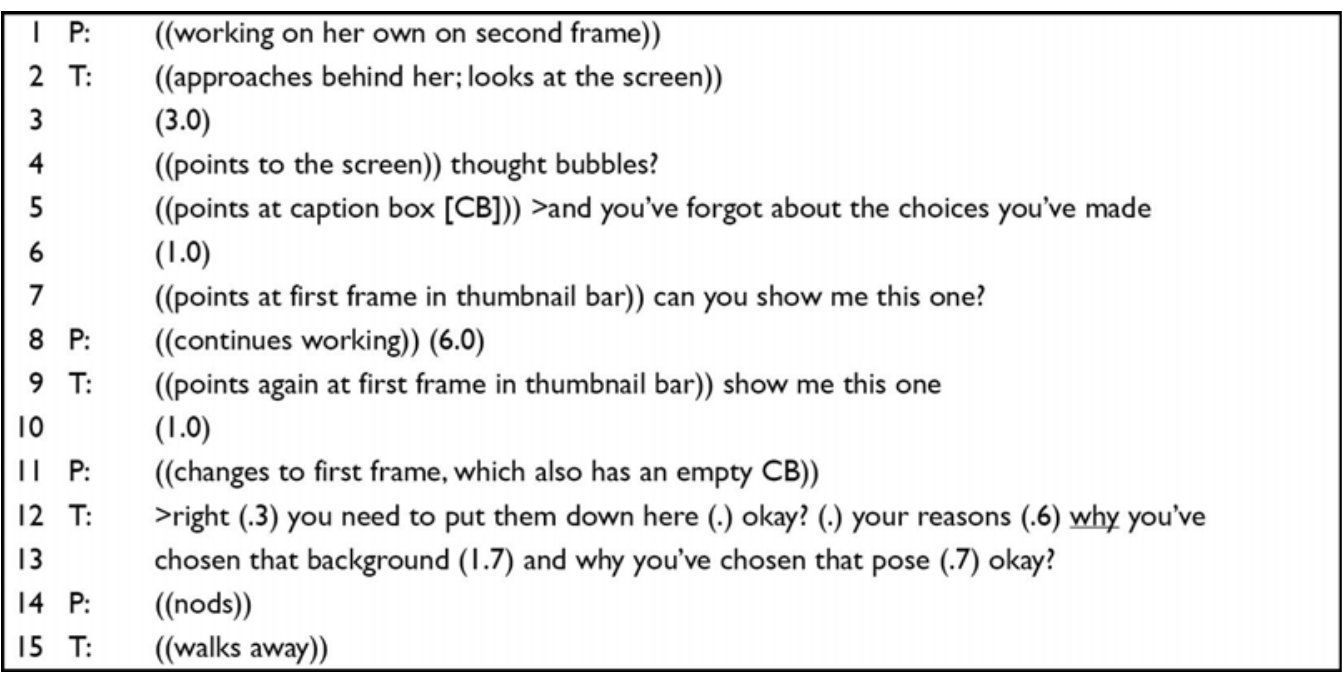

When looking at the frame the pupil is currently working on, the teacher points out that the pupil has not inserted any thought bubbles (line 4), although the teacher had previously told the class that thought bubbles were supposed to depict "what you think that they are really thinking” [Feb 16; first computer lesson]. Furthermore, neither has the pupil written "the choices" (for constructing the picture in the way she had) in the caption box (line 5). The teacher then asks the pupil to show her the previous frame. The thought bubble and caption box have not been done in the current frame, but the pupil may still be planning to get to them. However, the caption box in computers. Forthcoming in International Journal of Computer-Supported Collaborative Learning (ijCSCL). 
the previous frame is also empty, which is more damaging, since it suggests that this is a habitually neglected part of the task. Consequently, the teacher repeats the reminder about the writing in the caption box (lines 12-13). What is noteworthy is that the teacher does not directly reprimand the pupil for not fulfilling an aspect of the task, but formulates her suggestion as something that the pupil "forgot".

Part of the reason for 'making rounds' is to check whether pupils are completing all important aspects of the task and to remind them if they fail to do so. In other words, pupils will not always, without prompting, tackle every aspect of the task automatically. There will always be aspects that pupils will treat as, at least initially, too difficult, too boring, or too cumbersome and therefore try to avoid (while for the teacher it may be precisely those aspects that are important). As the lessons progressed, it became clear that many pupils did not complete the caption box aspect of the task. Consequently, the teacher would frequently remind both specific pupils as well as the whole class to make sure that they wrote their choices or reasons in the caption box. ${ }^{4}$ The next fragment is just one of many examples:

${ }^{4}$ In a post-lesson interview the teacher remarked to me that the pupils are "so taken with the pictures which is great (.) but they're not getting their reasons in”.

Greiffenhagen, C. Making rounds: the routine work of the teacher during collaborative learning with computers. Forthcoming in International Journal of Computer-Supported Collaborative Learning (ijCSCL). 


\section{Fragment 6 [Mar 9; fifth computer lesson]}

\begin{tabular}{|c|c|c|c|}
\hline 1 & & ((pupils working on thought bubbles in fifth frame)) & Fin \\
\hline 2 & & ((caption box is still empty)) & \\
\hline 3 & Nick: & ((typing in the thought bubble of Macbeth)) & \\
\hline 4 & $\mathrm{~T}:$ & ((approaches behind pupils)) & \\
\hline 5 & Nick: & ((stops typing)) & $m=$ \\
\hline 6 & & ((turns towards teacher)) & \\
\hline 7 & & how do you spell outrageous? & \\
\hline 8 & $\mathrm{~T}:$ & a geous (.) out (.) rag (.) e ous & \\
\hline 9 & Nick: & $(($ corrects spelling $))(4.0)$ & \\
\hline 10 & & ((looks at teacher)) & \\
\hline 11 & $\mathrm{~T}:$ & question mark? & 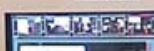 \\
\hline 12 & Nick: & yeah & \\
\hline 13 & & ((inserts question mark)) & \\
\hline 14 & $\mathrm{~T}:$ & okay $($.$) and then why: you've chosen$ & \\
\hline 15 & & that ((points at construction window)) & \\
\hline 16 & & down there ((points at caption box $))$ & \\
\hline 17 & & $(($ walks away)) & \\
\hline
\end{tabular}

The teacher approaches behind two pupils who are currently writing their interpretation of Macbeth's speech in the thought bubble of Macbeth. Nick (on the right) is unsure how to spell 'outrageous' and asks the teacher for advice (line 7). Once Nick has corrected the spelling, he again turns to the teacher (line 10), possibly to check whether he has spelled the word correctly or to see whether there is anything the teacher would like to comment on. In turn, the teacher points to some missing punctuation (line 11). After Nick has inserted a question mark, the teacher reminds the pupils about the writing in the caption box (lines 14-16).

What is remarkable about the teacher's utterance is its placement. That is to say, the teacher does not remind the pupils of an aspect of the task they forgot to do in a completed frame (as the teacher did in Fragment 5, where she checked whether the caption box was empty in the previous frame). Rather, the teacher reminds the pupils of something that they will have to do in the future. In the summary formulation of the task, the teacher had suggested a four-step sequence for each frame - picture construction, speech bubbles, thought bubbles, and caption box - which most pupils followed. Since the pupils are currently working on the thought bubbles, it is not really that 
they have 'forgotten' to write in the caption box, since it is next thing they should do. It is more that the teacher expects that they might skip over that step and that she therefore emphasises that the next thing they should do is to work on the caption box (rather than, say, start a new frame). In this context, it is significant that this is already the fifth computer lesson and the teacher will have gathered a lot of experience of 'typical' problems, in particular, pupils' unwillingness to complete the caption box aspect of the task.

Although pupils often did not write in the caption box, this does not mean that they were not aware of this aspect of the task. This is visible in the next fragment (for a detailed analysis see Birmingham et al., 2002): 


\section{Fragment 7 [Mar 5; third computer lesson]}

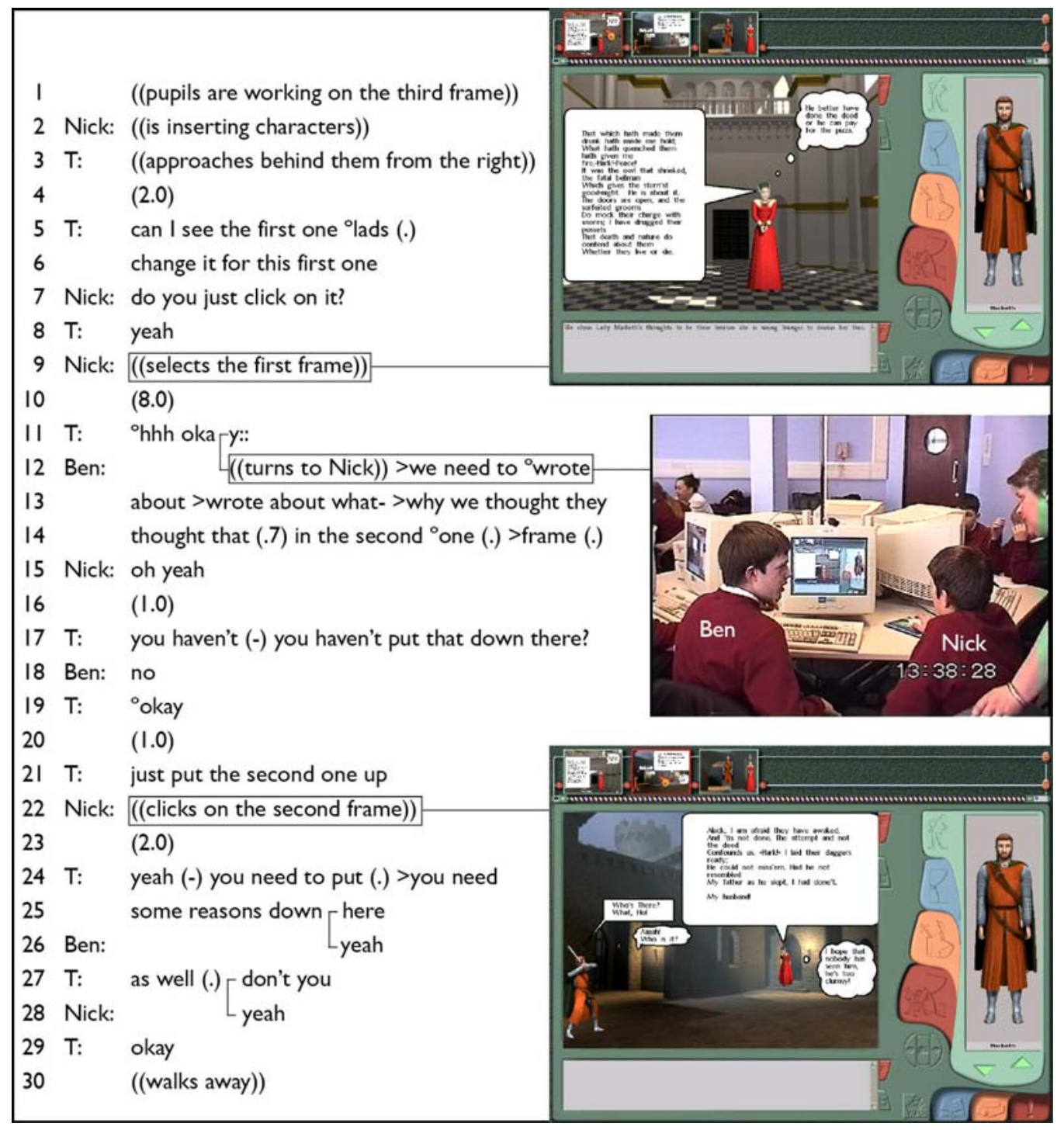

The teacher approaches the pupils (who have just started to work on their third frame) and asks them to change to the view to the first frame (lines 5-6). The teacher then looks at that first frame for a long time, without saying anything (line 10), probably reading what the pupils have written in the thought bubble ("He better have done the deed or he can pay for the pizza.") and caption box ("We chose Lady Macbeth's thoughts to be these because she is using hunger to descise [sic] her fear.”). Just as the teacher starts to speak again (line 11), Ben (sitting on the left) turns towards Nick (and the teacher) and remarks that they still have to write "why we thought they 
thought that” in the second frame (lines 12-14). Nick agrees with Ben (line 15) and the teacher provides a reformulation of this omission (line 17), before asking to see that second frame (line 21). Once she has looked at the frame for a few seconds, she repeats Ben’s formulation that they need "some reasons down here as well".

This fragment is noteworthy because it is one of the pupils who addresses their failure to complete the caption box requirement of the task. Note that this admission actually occurs in such a way that it could be seen to pre-empt the teacher's criticism: Ben starts to talk precisely at the moment at which the teacher has spent a long time looking at the first screen and starts to speak again. At this point the pupil can expect the teacher to ask them to move on to the next frame (she has ratified the first frame and is now likely to check the second frame). Since they have not written in the caption box in the second frame, this would result in a negative evaluation by the teacher (in contrast to the "okay” on their first frame). Ben’s acknowledgement of their omission thus pre-empts a potential criticism by the teacher.

What this episode demonstrates is that although pupils often did not write in the caption box, it was not that they were not aware of this aspect of the task. It was rather that the pupils, on occasion, displayed a difference in orientation to that of the teacher in what they considered important or interesting in the current activity. In other words, sometimes what pupils deemed interesting diverged from the teacher's educational aims for the current task (this will be taken up below).

\section{Making suggestions}

The caption box requirement was explicitly mentioned in the initial formulation of the task and the teacher could therefore simply remind pupils about it. However, a lot of the teacher's specific comments to pupils during her rounds were not a simple reminder of something that the she had already told them, but rather dealt with the specific ways in which the pupils were completing the 
task (i.e., with how pupils were figuring out how to complete the task in a satisfactory way). In the next fragment, the teacher picks up on the question of how much text from Shakespeare's text should be placed in each frame:

Fragment 8 [Mar 2; second computer lesson]

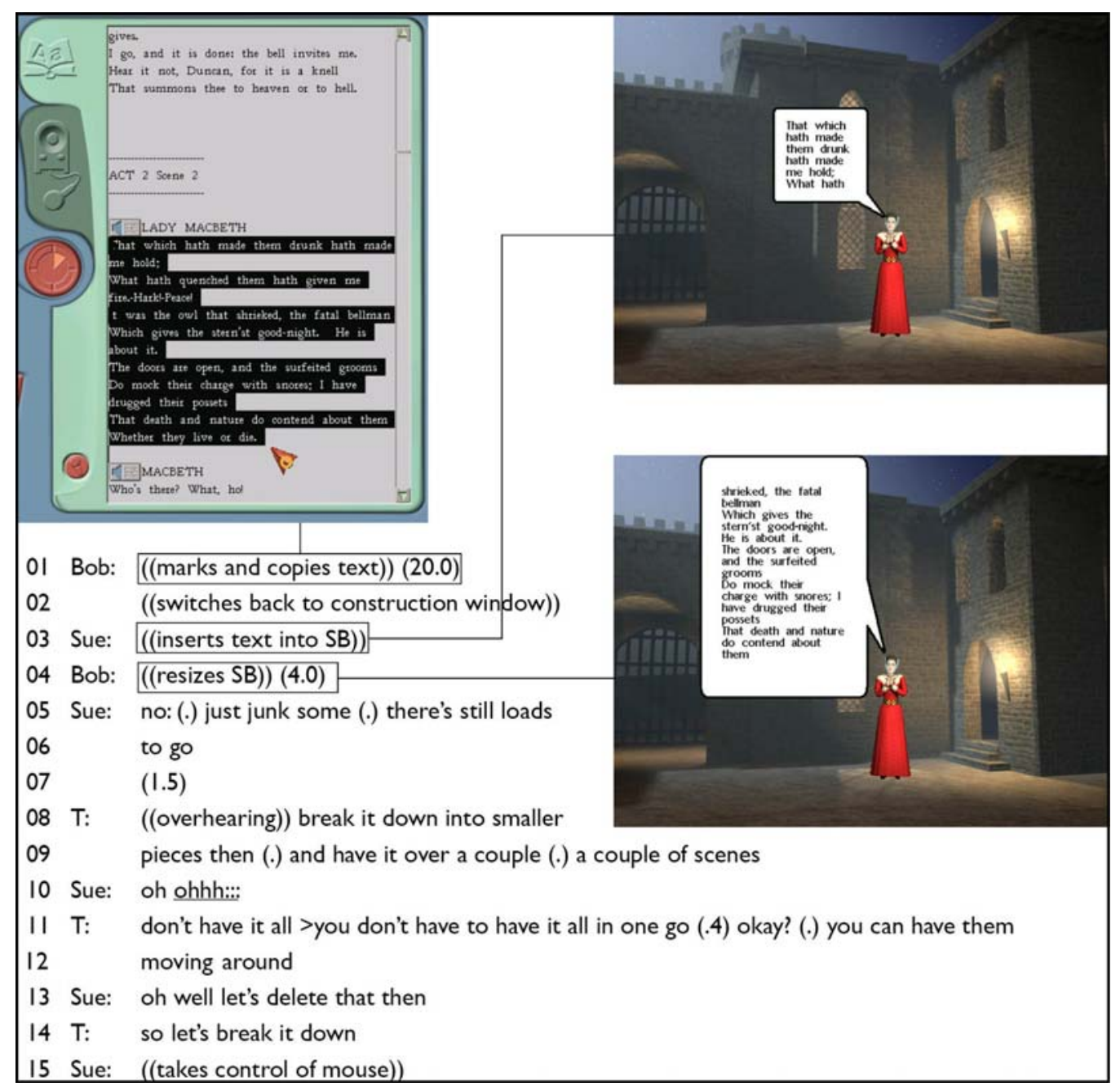

The two pupils are working on their first frame. One of them (Sue) has copied a large piece of text into Lady Macbeth's speech bubble. In fact, it is so much text that it does not fit into the speech bubble. The other pupil (Bob) tries to solve this problem by resizing the speech bubble, i.e., making it bigger (line 4). However, even the enlarged speech bubble cannot display all the computers. Forthcoming in International Journal of Computer-Supported Collaborative Learning (ijCSCL). 
copied text. In response to this, Sue suggests to "just junk some” (line 5), i.e., to delete some of the text.

The teacher overhears this and suggest to the pupils to "break it [Lady Macbeth's monologue] down into smaller pieces” (line 8), i.e., to have the monologue “over a couple of scenes” (line 9). The teacher does not only propose this as a good solution to the technical problem (of too much text for a speech bubble), but also gives a rationale in terms of the task. The pupils are supposed to visualise a scene from a play, where a person who gives a long monologue would typically not stand still. Therefore the pupils should have them the characters "moving around" (line 12), which is exactly what the pupils subsequently do (Figure 2).
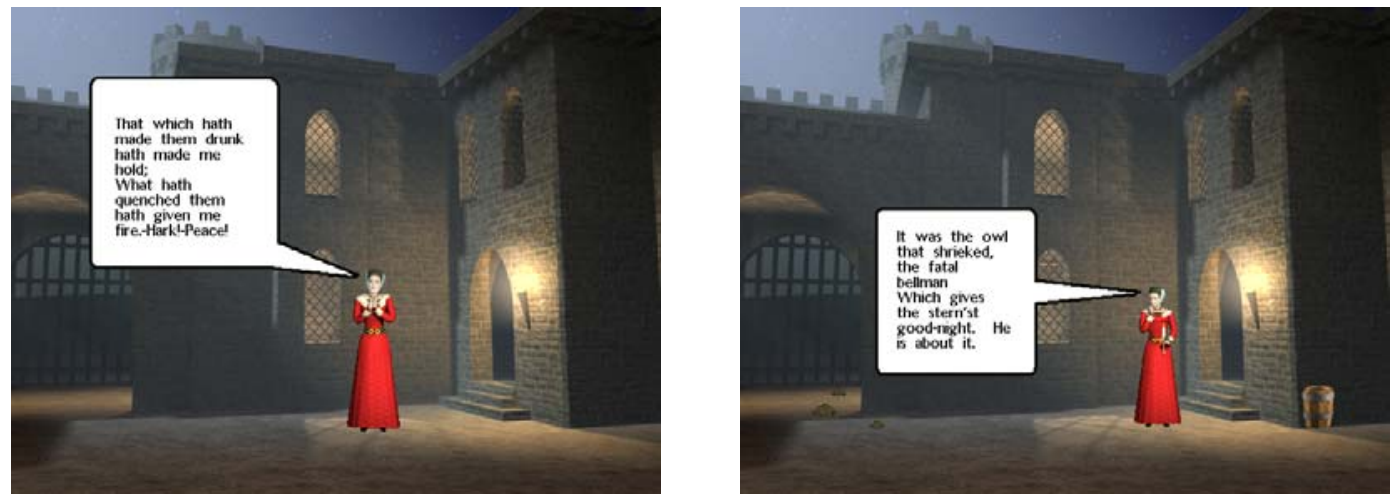

Figure 2: the frames at the end of the lesson

The teacher in this fragment does not remind the pupils of something that they have forgotten to do. In her initial formulation of the task the teacher had not made any specification about 'how much' of Shakespeare's text should be placed in a speech bubble. However, when the teacher is confronted with this potential solution, she does not accept it. This way of visualising the scene is not how the teacher wants pupils to complete the task. The teacher here elaborates on her original instruction, which points to the recursive nature of tasks: once the pupils have begun to carry out the instructed actions, each of the original instructions might be further expanded, clarified, corrected, etc. as needed (cf., Greiffenhagen, 2008). 
Note that the teacher does not just say that what the pupils are doing is wrong. Rather, she also makes a suggestion of what to do instead, i.e., how to correct what in the teacher's eye is currently wrong with their work: they should break the text into smaller pieces (line 8), have it over a couple of scenes (line 9), and have the characters moving from frame to frame (line 12).

It may be tempting to suggest that we have here a situation in which two different parties have two alternative, equivalent, suggestions, but that it is due to the teacher's authority or power that one of the alternatives is selected. However, this way of characterising the situation would miss what the teacher is trying to do. The teacher's suggestion is not just different, but also more complex, complicated, and challenging. It requires the pupils to do more than they are currently doing: rather than having one frame for Lady Macbeth’s entire monologue, they will have to have at least two frames and think about how to depict Lady Macbeth in each of them. In other words, it is not so much that the teacher tells the pupils to do it her way, but that she challenges the pupils to come up with a more sophisticated solution to the one they have done so far. It is a suggestion that is supposed to stimulate more imaginative work from the pupils.

As mentioned above, pupils often did not write their 'reasons' in the caption box. If they did, it often seemed that their main concern was to write 'anything' so that they could be seen to at least formally comply with the requirement. One of the problems for the teacher was thus to encourage pupils to spend more effort in finding formulations for the caption box. In the next fragment, the teacher approaches behind two pupils who have written a rather minimal account of their frame in the caption box, namely: "Macbeth is guilty and he knows it. Lady Macbeth is reflecting on her poor past.” (see Figure 3). They are now in the process of scrolling through the text of the play in order to find the part of the dialogue that they will insert into the next frame. 
Page 26 of 52

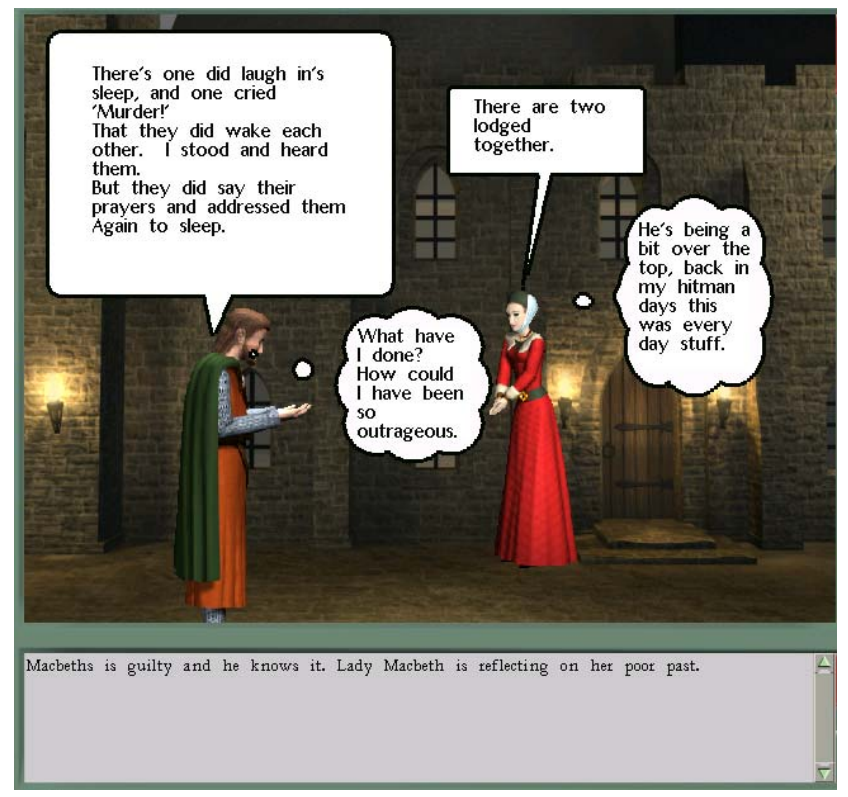

Figure 3: the current frame [reconstructed]

Greiffenhagen, C. Making rounds: the routine work of the teacher during collaborative learning with computers. Forthcoming in International Journal of Computer-Supported Collaborative Learning (ijCSCL). 


\section{Fragment 9 [Mar 12; sixth computer lesson]}

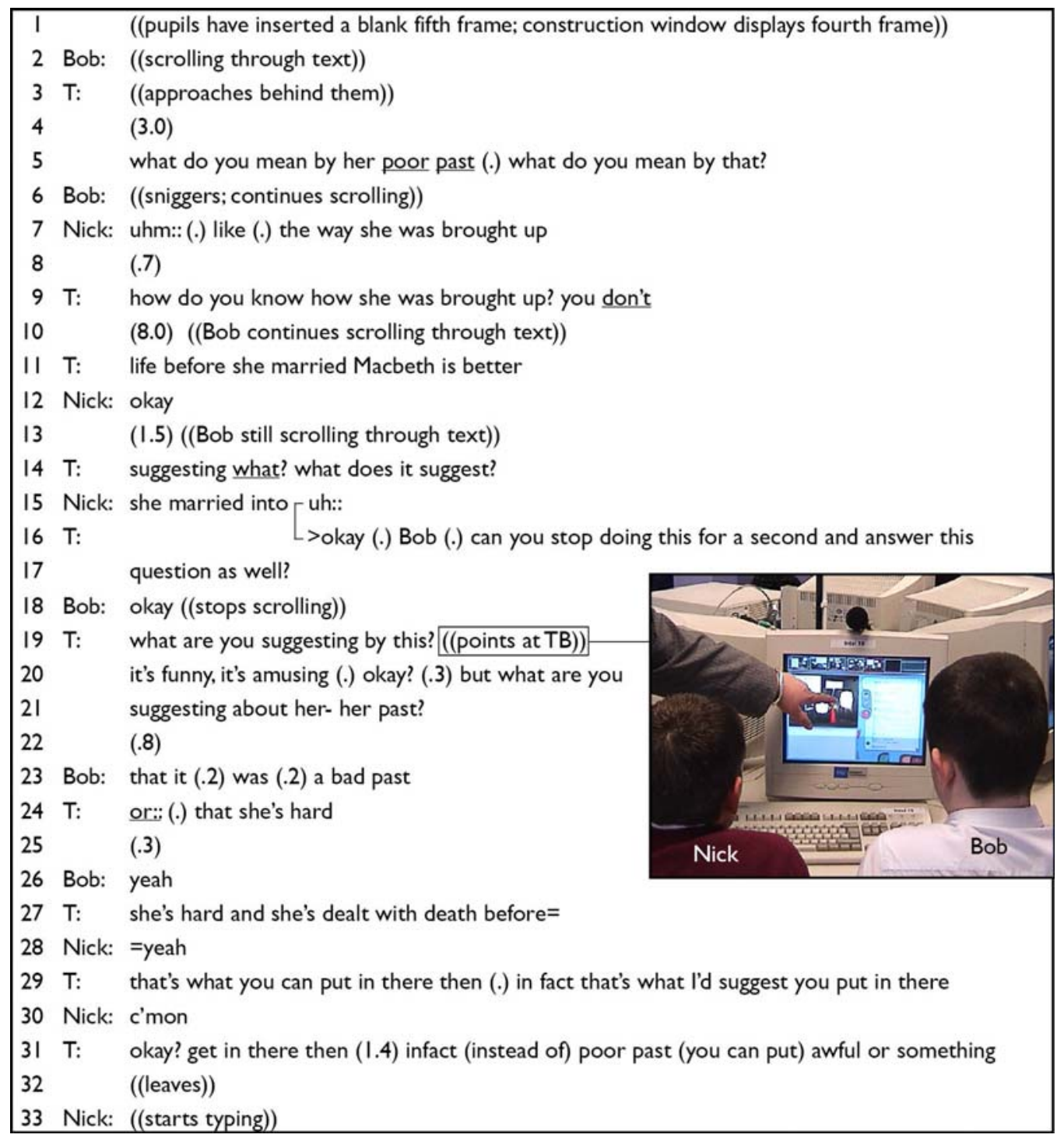

The teacher starts by asking the pupils about the text they have written in the caption box. Nick (who was the one who had written that text) tries to answer the teacher's question: he explains that they were referring to "the way she was brought up" (line 7). This is not accepted by the teacher who argues that they do not know how Lady Macbeth was brought up (line 9). After a long pause, the teacher makes an alternative suggestion; they could instead write: "[Lady Macbeth is reflecting on] the life before she married Macbeth” (line 11). computers. Forthcoming in International Journal of Computer-Supported Collaborative Learning (ijCSCL). 
The teacher then focuses on the thought bubble of Lady Macbeth (which currently reads "He's being a bit over the top, back in my hitman days this was everyday stuff.") and asks the pupils what they are suggesting by this. The teacher clearly does not accept what the pupils have written in the thought bubble, but she does not directly tell them so. She characterizes what they have written as "funny" and "amusing" (line 20) and marks the content of the thought bubble as outside the realm of the assignment. Nevertheless, she uses the content as a resource for pursuing further reflection, asking the pupils what they are trying to express (line 21). Bob gives a candidate answer: they are trying to suggest that Lady Macbeth had a "bad past" (line 23). To this the teacher offers an alternative: Lady Macbeth is "hard" (line 24) and "has dealt with death before” (line 27). These suggestions get accepted by both pupils.

The teacher clearly is not satisfied with what the pupils have written in the caption box and the thought bubble. In contrast to the previous fragment, where the teacher gave the pupils a new problem which they were supposed to solve, in this fragment the teacher makes a relatively explicit suggestion as to what the pupils should write. In fact, the pupils subsequently write almost word-by-word what the teacher suggested ("Macbeth is guilty and he knows it. Lady Macbeth is reflecting on her life before she married Macbeth. It shows that she is hard and tough and has dealt with death before.”). What is interesting is that the teacher's suggestions preserve aspects of the pupils 'inappropriate' solutions. That is to say, the teacher does not completely dismiss the pupils' current solutions, but rather transforms or 'revoices' (cf., O’Conner and Michaels, 1993) them. From "poor past” to "her life before she married Macbeth”; from "hitman days" to "she is hard and tough". Rather than dismissing what the pupils have done, the teacher marks it as partially inappropriate and makes a suggestion how they can transform their text so it fits with the teacher's conception of the task and thereby into the context of an English lesson on Macbeth. Thus, again, we can see the teacher not being completely negative about what pupils have done (although this is marked as inappropriate), but as challenging them: what they are 
doing is funny and amusing, but they have to be more explicit in terms of their suggestions and to try to link it to the content of the play.

When reviewing what pupils have done so far, the teacher frequently came across work that although not 'wrong' or 'incomplete' went against the pedagogic aims of the task. In such cases, the teacher typically did not just tell pupils that there is a problem with their work, but furthermore explained why there is a problem and formulated a candidate solution for how to rectify it (thereby prompting them to produce further work). In doing so, the teacher frequently reoriented pupils to the 'point' of the task (i.e., to the aims of the current activity). This is, perhaps paradoxically, something that is a particular problem for activities that are seen as 'fun' by pupils, since pupils can loose the focus on what they should, educationally, be getting from the activity. Consequently, teachers have to, continuously, reorient pupils to what is educationally important.

\section{Maintaining classroom control}

Not everything the teacher does while making rounds is related to academic aspects of the lesson.

Part of the reason for walking around has to do with classroom management (cf., Macbeth, 1990, 1991), i.e., with establishing and maintaining classroom discipline control (which means, minimally, that pupils should be sitting on their seats, not talk too loudly, and at least appear to be working). The next fragment gives a rather peculiar illustration of how the teacher can accomplish this: the pupils making various jokes about their current frame (Figure 4), which contains a piece of dung and which leads one of them to characterize Chris (sitting on the computer to their left) as "a donkey-faced mule". On hearing this, Chris starts to lean over, making several comments. The teacher spots this and quietly appears behind Chris. 
Page 30 of 52

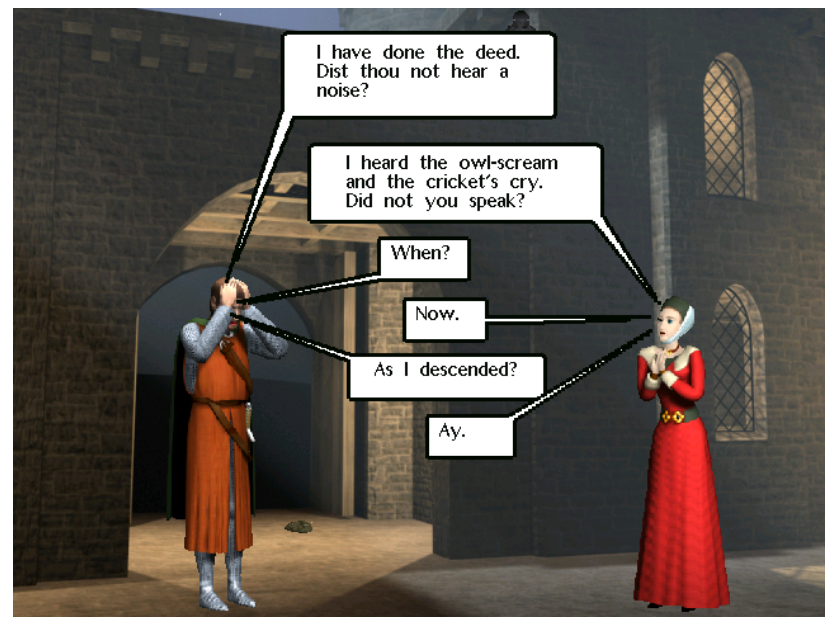

Figure 4: current frame [reconstructed]

Greiffenhagen, C. Making rounds: the routine work of the teacher during collaborative learning with computers. Forthcoming in International Journal of Computer-Supported Collaborative Learning (ijCSCL). 


\section{Fragment 10 [Mar 5; third computer lesson]}

\begin{tabular}{|c|c|c|}
\hline 1 & Nick: & $(($ working on third frame $))$ \\
\hline 2 & & I'm not a (donkey-faced mule) \\
\hline 3 & Ben: & yeah you are \\
\hline 4 & Nick: & no (.) that's Chris \\
\hline 5 & & $(.5)$ \\
\hline 6 & Chris: & what did you call me? \\
\hline 7 & Ben: & a (donkey-faced mule) \\
\hline 8 & Chris: & you betta $()>$. you betta not have \\
\hline 9 & & $(($ leans over $))$ \\
\hline 10 & Ben: & now you ca:n (.) click on it \\
\hline 11 & & $(1.0)$ \\
\hline 12 & Chris: & Nick:: $[$ (.) there's you ((points at dung)) \\
\hline 13 & Ben: & $L_{\text {are we gonna do what they're }}$ \\
\hline 14 & & thinking \\
\hline 15 & Nick: & ((changes to text screen)) \\
\hline 16 & Chris: & heheheheh $(.3)$ there's you \\
\hline 17 & & $(($ points again $))$ \\
\hline 18 & Pete: & ((also glances) $)$ \\
\hline 19 & Nick: & ((changes to composition screen)) \\
\hline 20 & & $(.5)$ \\
\hline 21 & Chris: & there's you ((still pointing)) what's that? \\
\hline 22 & Ben: & La crow \\
\hline 23 & $\mathrm{~T}:$ & ((approaches behind Chris)) \\
\hline 24 & Chris: & a crow (.) looking \\
\hline 25 & $\mathrm{~T}:$ & $\mathrm{BOO}$ \\
\hline 26 & Chris: & ((turns around)) \\
\hline 27 & Pete: & he hehehehehehe \\
\hline 28 & Ben: & ${ }^{L}$ he hehehe \\
\hline 29 & Nick: & $\mathrm{L}_{\text {hehehe }}$ \\
\hline 30 & Chris: & ((moves back to his computer $))$ \\
\hline 31 & $\mathrm{~T}:$ & $(($ walks away $))$ \\
\hline
\end{tabular}

Nick and Ben are working on their frame, although currently they seem to be 'joking around'.

Nick suggests that Chris (the pupil sitting to their left) could be a "donkey-faced mule”. Upon hearing this, Chris leans over, looks at the screen (line 9), and then continues with the 'name calling', choosing Nick as his target (line 12). When Chris continues with this, even Pete (sitting on the far left) glances to the computer of Ben and Nick (see the picture attached to line 18).

Greiffenhagen, C. Making rounds: the routine work of the teacher during collaborative learning with computers. Forthcoming in International Journal of Computer-Supported Collaborative Learning (ijCSCL). 
While this is going on, the teacher slowly appears behind Chris, placing her hands on the back of his chair. After standing there for a moment, the teacher utters the sound "BOO”, which prompts Chris to turn around and solicits laughter from the other pupils. Chris quickly turns his attention to his own computer and the teacher leaves.

Obviously, pupils are not 'on task' all the time, but by making rounds the teacher can minimize 'off task' behaviour. In this episode, one pupil (Chris) is visibly not working on the task: he is not looking at his own screen but at the screen of other pupils; furthermore, he is not helping them (which might be acceptable), but is rather engaged in some form of banter. What is so lovely about the teacher's intervention is that she does not have to say anything. The way the teacher creeps up behind Chris makes visible for everyone except Chris that he is under surveillance and displays that there is something sanctionable about his current behaviour. The teacher's surveillance is brought to his late attention through the 'BOO'. Although not a 'quiet reproach' (Macbeth, 1990), it is a reproach that does not need to be explicitly formulated. That is to say, the teacher's "BOO" (line 25) is hearable as a reproach without the teacher having to say to Chris something like “stop what you're doing” or "get back to your work”. Instead, the teacher can rely on shared norms of the classroom for Chris to do just that. Furthermore, it is not just Chris who hears the teacher in this way, but also the other pupils who react to the teacher's "BOO" with collective laughter, exhibiting that they can easily hear the teacher's utterance for what it is meant to me: a non-explicit reproach.

Although good-humoured, after all this is a minor offence, episodes such as this are still vital for establishing classroom control: pupils are aware that the teacher may approach them - or just look at what they are doing from the other side of the room - and this potentiality helps to keep them from departing from 'acceptable' classroom behaviour too often or too much. In that sense, it is not just the teacher who monitors pupils, it is also pupils who monitor the teacher (pupils often quickly check whether the teacher is looking at them before engaging in 'off-task' computers. Forthcoming in International Journal of Computer-Supported Collaborative Learning (ijCSCL). 
activities). In the current fragment, Chris is so engrossed in the exchange with Nick and Ben that he does not notice that the teacher is approaching behind him. Indeed, the teacher manages to lean on the back of his chair without Chris becoming aware of her presence (in fact, for a few seconds the teacher mimics Chris’s body movement, moving backward when Chris is moving backward). In that sense, the teacher's "BOO” is a surprise and has a 'caught you (in the act)' character, since she has given Chris an opportunity to see for himself that he needs to get back on task (simply by approaching behind him).

In sum, pupils do not have to be seen to be 'on task' all the time, but neither can they be seen to be 'not working' too often. Furthermore, teachers can and do expect that pupils will watch and monitor for their approach and adjust their behaviour accordingly.

\section{Making whole-class announcements}

When reviewing the work of individual pupils, one question the teacher has to ask her- or himself is whether the current problem (or solution) is specific to these pupils or whether it could be relevant to other pupils as well. In the case of the latter, the teacher may choose to make an announcement to the whole class. In the next fragment, the teacher tells the class that if they want a character in the same size and pose as in a previous frame, they can drag and drop the character from the thumbnail of that frame (in the thumbnail bar) into the current frame (rather than inserting the character from the databank and then changing the size and pose manually):

\section{Fragment 11 [Mar 2; second computer lesson]}

$\begin{array}{lll}\text { I } & \text { T: } & \text { I just found out folks (.) if you want to copy (.) just copy the pose into the next (.5) frame (.9) } \\ 2 & \text { you click on new frame at the top (.) so you got a blank one appearing at the top (.5) at the bar } \\ 3 & \text { across the top yeah? (.6) and then just click on the figure you want to copy (.) and drag it } \\ 4 & \text { out (.9) to the new frame (.) and it will just copy itself up there }\end{array}$

What is interesting is that the teacher's announcement is presented as being touched-off (cf., Sacks, 1992; Winter 1969, Lecture 1) by what the teacher has observed other pupils doing. In 
other words, she does not simply tell the class what to do, but says that she "just found out" (line 2). This is even more explicit in the next fragment, taken from the fourth computer lesson, in which the teacher instructs the class to make use of the scale feature of the software:

\section{Fragment 12 [Mar 6; fourth computer lesson]}

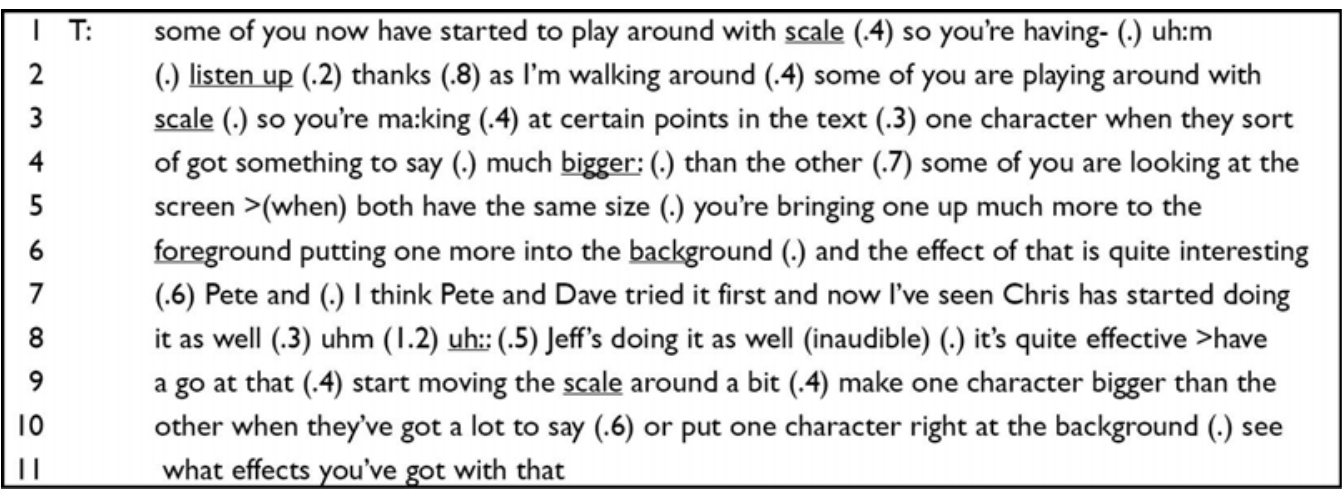

In situations such as these, the teacher is sharing a solution found by particular pupils. The reason for sharing is that it is likely that other, if not most, pupils will have encountered or will encounter the same problem; sharing the solution will thus save time and effort. The teacher is, in effect, broadcasting a solution to the whole class, since it is difficult for these to spread effectively without the help of the teacher. In this case, the teacher is producing the scaling feature of the software as a 'technical' discovery, but thereby simultaneously adds a new facet to the task.

The teacher's suggestion is again not presented as something that the teacher has thought of completely on her own, but as something that she has observed in the work of pupils. For the logic of making such a statement, it is irrelevant whether "as I'm walking around some of you are playing around with scale" is a 'correct' description of why the teacher is making this announcement, since the pupils are in the same position as the researcher and cannot 'verify' whether what the teacher is saying is true. What is important is that the scale function is not introduced as something simply requested by the teacher, but as something observed by her, i.e., as something that was 'discovered' by pupils and not by the teacher. This might be an effective 
device used by teachers in order to motivate others pupils to try this out, since it allows the teacher to appear not as the 'director' (telling pupils what to do), but more as a 'moderator' (communicating to the class what she has observed other pupils doing).

Of course, the teacher not only announced 'positive' examples, but also 'negative' ones, in particular, the failure of many pupils to write in the caption box:

\section{Fragment 13 [Mar 6; fourth computer lesson]}

\begin{tabular}{|c|c|}
\hline I T: & when I'm going round I'm seeing (.) Sarah? (I.0) some fantastic (I.0) scenes (.) there's some \\
\hline 2 & really nice ones (.) there's some great stuff coming on (.8) what l'm a bit concerned about is (.) \\
\hline 3 & that a lot of you aren't putting anything in the explanation boxes at the bottom (.) telling me \\
\hline 4 & why you've done what you're doing $(.7)$ there are gonna be merits and stuff $($.$) going at the end$ \\
\hline 5 & of this (.) alright? for the ones that are most effective >and what l'm going to be looking at (.8) \\
\hline 6 & although the pictures are important $>$ l'll be looking at the thought bubbles $(.7)$ and what's \\
\hline 7 & written in that bottom box (.) I want to be able to see (.4) what's made you make the decisions \\
\hline 8 & that you've made (.) why you've made the choices that you've made $(.7)$ so can you make \\
\hline 9 & su:re (.4) that that grey box at the bottom of each scene has been filled in as you go along (.4) \\
\hline 10 & why you've chosen (.) to portray the characters the way you have $(.2)$ why they're thinking what \\
\hline 11 & they're thinking >why they're standing the way they're standing $(.3)$ why you've chosen that \\
\hline 12 & background \\
\hline 13 & {$[\cdots]$} \\
\hline 14 & so whilst this is a great exercise (.4) your director's board (.) it is (.) I need to know why you're \\
\hline 15 & making those choices $(.3)$ cos that's what's going to get you through your SATs $(1.0)$ you're not \\
\hline 16 & going to have kar2ouche in your SATs unfortunately >it would be wonderful if you could (I.0) \\
\hline 17 & what you are going to have to write down (.) is why you think characters are saying what \\
\hline 18 & they're saying at a certain time (0.7) so get that- >those boxes filled in please \\
\hline
\end{tabular}

The teacher reprimands the pupils for not having put "anything in the explanation boxes at the bottom" (line 3). As in the case of the scale functionality (Fragment 12), the announcement is presented as being touched-off by what the teacher has observed ("when I'm going round I'm seeing”). However, there are some important differences. Firstly, the teacher does not launch directly into her criticism, but prefaces it with praise (“fantastic (.) scenes”, "really nice ones”, "great stuff"). This is a familiar feature of criticism, where one first points out a positive feature, before launching into problems (“it's really nice, but...”). In other words, the criticism is cushioned through the initial compliment. Note how the positive evaluation is formulated as only applying to some frames ("some fantastic scenes”, "some really nice ones”, "some great stuff”), 
whilst the negative evaluation is formulated as applying to "a lot of you". In other words, a few positive instances are used to mitigate the criticism of the majority of the pupils. Secondly, although in both fragments the teacher instructs the pupils to do something (to use the scale function and to write their reasoning in the caption box respectively), in the 'positive' case, the teacher had named individual pupils that had touched off her announcement, but in the 'negative' case she does not do so, but only speaks of "a lot of you” (line 4). In other words, she formulates her request as a generalised corrective that does not allow its recipients to determine which (if any) individuals are the occasion for it and whether there really are "a lot of you". The teacher indicates that it is not important who did not write in the caption box, as long as everybody who hasn't done so corrects this. The teacher’s formulation makes clear that every pupil should check whether the criticism applies to her or him.

Finally, the teacher gives reasons for why pupils should be writing in the thought bubbles and caption box. The teacher emphasises that in her evaluation of the task, "although the pictures are important" (line 6), her emphasis will be on the thought bubbles and the caption box. This emphasis on the written elements (thought bubbles and caption box) over the picture is further accounted for by reference to the SATs (lines 15-18). The teacher thus informs pupils that the thought bubble and caption box aspect of the current task is more directly related to the eventual assessment than the composition of the picture. What is educationally noteworthy about the current task is tied to what the pupils will eventually have to do in the written exam. The teacher thus again re-orients pupils to the 'point' of the task (since they are having too much 'fun').

\section{Linking this activity to the exams}

This brings us to a final aspect of the work of the teacher during collaborative work, which has to do with the 'double duty' these activities perform. On the one hand, most computer-supported collaborative learning activities which are embedded in real classroom contexts (rather than in 
experimental situations) are worthwhile 'stand alone' activity. On the other hand, most of them are also embedded in a larger programme of work, often with the explicit aim of preparing pupils for an exam. In our case, although the storyboarding activity as clearly in itself a worthwhile way to engage pupils with Macbeth, it was also meant to prepare for their final examination.

In the last fragment we had seen the teacher explaining to pupils the need to write in the caption box by reminding them that they would not have the software as part of their exams. A similar announcement is made two lessons later:

\section{Fragment 14 [Mar 12; sixth computer lesson]}

\begin{tabular}{|ccl|}
\hline I & T: & UHHH (.4) Year (.) Nine (.) as I walk around (.5) I find that you haven't all written in your \\
2 & reasons underneath the screens $($.$) why (.4)$ you've made the choices you've made $(.8)$ UHH: $()$. \\
3 & thank you (0.4) LISTEN (I.6) uh: $($.$) thank you (I.0) ((class quiet now)) I was under the$ \\
4 & impression that you had all done this $(0.5)$ when I asked on (.8) Friday (.) I was su:re that you \\
5 & had all done this (.6) then I find that you haven't all done this >this is very, very important (.) in \\
6 & the SATs exam (.3) that's what you are going to be tested on (I.0) so if you've got any frames \\
7 & there that you have not written there underneath the reasons for your choices $(.5)$ in that \\
8 & particular frame get them written in now (.) and I'm going to come around to spot check
\end{tabular}

In this fragment, the teacher again touches off her announcement by stating that it concerns something that she has observed (line 1). She then provides another formulation of why the writing in the caption box is treated as so important, since it is this aspect of the task that they will be tested on (line 6).

This fragment nicely exhibits that although the storyboard activity was in a certain sense a selfcontained activity, it was also part of a larger project, the preparation for SATs. Lynch (1997 [1979]), in a study of pre-trial discussion among lawyers, argued that although the judge may not be present during these discussions, the participants still orient to the judge, e.g., by projecting what a judge might do. In other words, the judge is a 'scenic feature' of these discussions. Similarly, Sharrock and Anderson (1994) show how 'the user' is a scenic feature of engineering design projects, while Zemel et al. (2008, p. 83) demonstrate how a non-present actor can be still 
be relevant for the ongoing interaction. In our case, we might say that the exams (SATs) were a scenic feature of the storyboarding activity.

The term 'scenic feature' does not imply that the exams were the explicit focus all the time. For example, the SATs were not mentioned during the very long introduction of the task. However, the SATs could be invoked at any point, for example, in explaining why correct spelling is important and why the teacher placed such great emphasis on the writing in the caption box. A perspicuous example can be found in our final fragment, in which the pupil asks the teacher whether Macbeth and Lady Macbeth can "live on a farm" (this fragment occurs about a minute after Fragment 10). 


\section{Fragment 15 [Mar 5; third computer lesson]}

\begin{tabular}{|c|c|c|}
\hline 1 & & ((the pupils are working on the thought bubble for Lady Macbeth)) \\
\hline 2 & Nick: & what's she saying $().(($ reading speech bubble $))$ I heard the owl scream and the cricket's \\
\hline 3 & & cry (.9) did not you speak? (.7) now? (1.0) ay (1.0) \\
\hline 4 & Ben: & ((starts typing in thought bubble)) \\
\hline 5 & Nick: & uh::: (2.8) why is he asking me this? (.8) of course \\
\hline 6 & & I heard a noise $(.3)$ we live on a farm don't - we? \\
\hline 7 & Ben: & L hehe \\
\hline 8 & Nick: & hehehe (.) ha ha \\
\hline 9 & & {$[\cdots](45.0)$} \\
\hline 10 & Nick: & we live on a farm don't we? hehe \\
\hline 11 & Ben: & they don't live on a farm! \\
\hline 12 & & $(.8)$ \\
\hline 13 & Nick: & hhh (.) MISS? ((raises hand)) \\
\hline 14 & & $(1.0)$ \\
\hline 15 & & d- can they live on a farm? \\
\hline 16 & Ben: & $>$ they don't live - on a ${ }^{\circ}$ farm \\
\hline 17 & $\mathrm{~T}:$ & can they live on a farm? \\
\hline 18 & Pn: & $($ (laugh and look at Nick) $)$ \\
\hline 19 & Nick: & yeah like c'n (.) can you make like this castle (.) \\
\hline 20 & & like into stables? (smiles)) \\
\hline 21 & $\mathrm{~T}:$ & {$[$ why- (.) >why do you want it into stables? } \\
\hline 22 & & (I.0) \\
\hline 23 & Nick: & cos like (.) if: they heard-iyuh a noise (.) she can go: \\
\hline 24 & & well of course I heard a noise (.) we live on a farm \\
\hline 25 & $\mathrm{~T}:$ & ${ }^{\circ}$ right \\
\hline 26 & & $(2.5)$ \\
\hline 27 & $\mathrm{~T}:$ & but it's kinda (.) it's kind of in the middle of nowhere \\
\hline 28 & & (.) isn't it? \\
\hline 29 & Nick: & yeah \\
\hline 30 & $\mathrm{~T}:$ & yeah $(1.0)$ so humorous though it is= \\
\hline 31 & Nick: & =yeah $($.$) hehe$ \\
\hline 32 & $\mathrm{~T}:$ & I think maybe if you put that in your SATs where they said y'know (.) what's Lady Macbeth \\
\hline 33 & & thinking when they (.) when they have this conversation (.) you put (.) I think she's thinking \\
\hline 34 & & we live on $\Gamma^{\mathrm{a}} \underline{\text { farm }}$ \\
\hline 35 & Nick: & Lhehehe \\
\hline 36 & $\mathrm{~T}:$ & I'm not sure you're going to pass your SATs (.) are you? \\
\hline 37 & Nick: & alright \\
\hline 38 & $\mathrm{~T}:$ & alright? \\
\hline 39 & Nick: & yeah \\
\hline 40 & $\mathrm{~T}:$ & okay ((walks away)) \\
\hline 41 & Ben: & okay what can he be thinkin'? \\
\hline 42 & Nick: & okay they don't live on a farm \\
\hline
\end{tabular}

The two pupils are considering what to write in the thought bubble of Lady Macbeth. One of the pupils (Nick) suggests that they should write that they live one a farm (line 6). The other pupil

Greiffenhagen, C. Making rounds: the routine work of the teacher during collaborative learning with computers. Forthcoming in International Journal of Computer-Supported Collaborative Learning (ijCSCL). 
proceeds to type in Macbeth’s thought bubble (line 9). Nick subsequently repeats his suggestion, which Ben does not accept (line 11). In response, Nick calls out to the teacher (line 13) and asks: “can they live on a farm?” (line 10-15). Nick's question is hearably 'unusual': when the teacher repeats the question (line 17), pupils sitting close to Ben and Nick start to look over and laugh (line 18); even Nick smiles (still attached to line 20). However, the teacher does not immediately dismiss the pupil’s question. Once Nick has produced an account of why he wants them to live on a farm, the teacher prompts Nick to give a further elaboration (line 21). When he has done so, the teacher provides a re-formulation of what the pupil is trying to express. The teacher characterises the suggestions as "humorous" and then uses the exams as a reason why it is unacceptable. As in some of the previous fragments (e.g., Fragment 9), the teacher preserves an aspect of the pupils' suggestion while simultaneously transforming it (cf., Sacks, 1992, Winter 1969, Lecture 9, p. 138).

Although the teacher's suggestion is eventually accepted by the pupil, I would suggest that this episode and the fact that pupils often did not write in the caption box point demonstrates that the orientations of the two parties are in several important respects different. The teacher, while appreciative of the fact that pupils were enjoying the storyboarding activity, wanted them also prepare for the exams. In contrast, the pupils occasionally seemed to be carried away with the purely pictorial aspects of the storyboarding activity (remember the teacher's remark in a postlesson interview: the pupils are "so taken with the pictures which is great (.) but they're not getting their reasons in”). Given their focus on the pictures, the writing in the caption box seemed for pupils to be a 'dirty work designation' (Hughes, 1971; Emerson and Pollner, 1976; Button and Sharrock, 1996, p. 382), i.e., constitutes work that they did not do for themselves, but only for others (the teacher).

The pupils needed little encouragement to produce the visual representation of the play. However, the teacher frequently had to remind them that the current activity - while certainly interesting computers. Forthcoming in International Journal of Computer-Supported Collaborative Learning (ijCSCL). 
and worthwhile - was also part of the preparation for their exams. Just as the teacher's suggestions were meant to keep pupils 'on task', so these remarks were meant to remind pupils to what was important if they wanted to do well in their exams.

\section{Discussion}

While it is clearly important how a teacher introduces a particular task (cf., Greiffenhagen, 2008), it is perhaps even more significant how the teacher subsequently follows the trajectory of that task, especially in situations in which pupils work on a task over several lessons. By 'making rounds' the teacher is able to monitor and assess how the pupils are working on the task and can then choose to ratify work that is proceeding along the right lines (e.g., Fragment 3), remind pupils of aspects of the task that they have neglected (e.g., Fragment 5), as well as make expansions, clarifications, and corrections in light of what the pupils are doing (e.g., Fragment 8). These interventions and announcements allow the teacher to deal with the recursive nature of tasks, which in a sense are given shape (reflexively and always revisable) through the workings of the pupils. The teacher does this both by talking to pupils individually as well as making announcements to the whole class (which are, interestingly, often formulated as being touched-off by what the teacher has observed other pupils to have done, e.g., Fragment 12). By walking around the classroom the teacher is also able to maintain order, making sure that pupils to a large extent display an appearance of working (Fragment 10).

When the teacher approaches pupils and looks at their work, pupils expect a reaction from the teacher. Teacher's interactions with pupils can be very brief, as in offering a passing remark or pointing out a spelling mistake (Fragment 6), or can be more prolonged and deal with more complicated matters, for example, when the teacher is not satisfied with what pupils have written in the thought bubbles and caption, but then uses that content as a resource to pursue further reflection (Fragment 9). On the whole, the teacher does not have much time for these 
engagements, since he or she cannot linger too long with a particular pair of pupils before other pupils begin to call for her or his attention (in Fragment 15, for example, you can see a girl in the back of the three stills who has her hand up throughout the exchange between Nick and the teacher). By paying close attention to what the teacher does, the aim has been to make visible those routine aspects of teaching, which are nevertheless essential for the accomplishment of successful lessons.

The emphasis in this paper has been on the perspective of the teacher and has only in passing discussed how the various comments were subsequently taken up by pupils (e.g., by looking at the storyboard at the end of the lesson as in fragments 8 and 9). Although it would be interesting to explore this in greater detail, the conceptual and methodological challenges should not be underestimated: Would we only examine those occasions in which pupils explicitly discuss the teacher's instructions? Or can pupils take up the teacher's instruction without any discussion?

The introduction raised the absence of detailed studies of the work of the teacher during collaborative activities and argued that this might be a reflection of the ambivalent status of teachers in theories and studies of collaborative learning. On the one hand, collaborative learning is seen as an alternative to traditional teacher-led instruction with the consequence that the teacher drops from view in pupils' activities. On the other hand, it has always been recognized that the teacher plays a crucial role in facilitating pupils' collaborative activities (e.g., Dillenbourg, 2008, p. 131).

What the teacher did in these fragments could variously be characterized as fruitful, stifling, encouraging, dismissive, too specific, not specific enough, etc. In particular, it may be tempting to distinguish between interventions that deal (only) with classroom management and those that engage in pedagogical interaction (the 'real' work of the teacher). What a close analysis of different types of teacher interventions shows is that it is rarely one or the other and that teachers 
are typically doing both at the same time (to varying degrees). When the teacher creeps up behind a pupil who is currently joking with other pupils and then surprises that pupil (Fragment 10), there is certainly little 'teaching' going on. However, when the teacher is correcting a spelling mistake (Fragment 4) or reminds pupils to work on their thought bubbles and caption box (Fragment 5), this is more difficult to characterize. Is the teacher only reinforcing the normative social order by maintaining her authority? Or is the teacher orienting pupils to the general educational aims of the activity (which had not just to do with constructing 'pretty pictures', but also with preparing them for subsequent writing assessments)? I think a strong distinction between 'management' and 'instruction' is difficult to maintain, since the two are in various ways intertwined.

Furthermore, although there are certainly tensions between the perspective of the teacher and those of pupils (as in which aspects of the task to spend most effort on), it would be wrong to characterize our episodes as antagonistic struggles, in which the teacher is trying to enforce authorized knowledge while the pupils are trying to discover things on their own. I think it would be difficult, for example, to distinguish instances in which the teacher interacts with pupils "in an intimate-egalitarian orientation” and those that are of "rigid authoritarian orientation” (categories 2 and 4 in Hertz-Lazarowitz and Shachar’s [1990] classification). For example, when the teacher suggests to pupils to "break it down" (Fragment 8), is that an instance in which the teacher tries to interact with pupils as a 'team member' or is the teacher giving instruction in an authoritarian fashion? Similarly, when the teacher does not accept what the pupils have written in the caption box (Fragment 9), she clearly draws on her authority, as she builds on and develops their work.

A very different reason for the absence of the teacher in studies of collaborative learning may perhaps be a consequence of the amazing success of computers in focussing pupils' - and researchers' - attention. That is to say, partly as a result of their novelty, but also as an expression of how computers are more 'fun' and engaging, and are so in a culture that highly values 
recreation, pupils often become easily engrossed in these activities. Both educationalists and teachers have been excited about this aspect of instructional technologies. As Roschelle and Teasley (1995) argued such technologies create a 'joint problem space’:

We see the 'computer-supported' contribution to collaborative learning as contributing a resource that mediates collaboration. In ordinary circumstances, one cannot imagine two 15 year olds sitting down for 45 minutes to construct a rich shared understanding of velocity and acceleration. But in the context of the support provided by the Envisioning Machine activity, our students were successful in doing just that. (p. 95)

This was also the case in our study. Both teachers remarked that the technology helped pupils to engage with Shakespeare's often difficult text in ways that would otherwise have been difficult. One teacher said (in a post-lesson interview): "The students loved it and what I found was that the kids remained focussed”. The other remarked: "I think for the lower end it's brilliant. Tom has jumped a National Curriculum grade at least. Just by the fact that it's visual for them and they find it easy do, they don’t realise that they're actually learning something, which is brilliant.” However, the way that technologies focus pupils' attention is not without hazards, since it may also become a distraction from and competitor to any educational aims the teacher may have in mind. In our case, some pupils became preoccupied with the pictorial aspects of the task, neglecting the fact that this was an English lesson (rather than an art class). One of the important aspects of the teacher's work is to constantly remind pupils of the important aspects of their task.

This brings us to a final point: while there is a relative absence of studies that take interest in the teacher's work and professional judgement, almost no study mentions how the computersupported collaborative learning activity relates to the exams that pupils will have to eventually take. While the problems of 'teaching to the test' are widely acknowledged, it is nevertheless the case that both teachers and pupils have to bear in mind that exams are an important aspect of classroom life. This study is a good example: The computer lessons with the storyboarding tool were nothing like 'drill and practice' as a direct preparation for the exams. Nevertheless, the 
exams were a 'scenic feature' of what the pupils were doing, allowing the teacher to emphasize both the importance of correct spelling as well as the continuing emphasis on the writing in the thought bubbles and the caption box. In order to create instructional technologies that will have a lasting impact, it is important to take account of this. As Dillenbourg and Jermann (2010, p. 535) rightly observe:

Teachers are not free to teach what they want; they have some degree of freedom in primary school, almost no freedom in secondary schools and a bit more at university level. Our community has been quite creative in designing activities that address skills that are not in the curriculum or only in the 'meta'-section with transversal skills. An extra-curriculum investment from teachers and students is acceptable for a short duration (the time of an experiment), but such an environment will not be used over long term if it is [not] justified by the importance of its learning objectives within the curriculum.

In that sense, it is not just the teacher who is absent from studies of computer-supported collaborative learning, but also the role that examinations play in collaborative learning activities (where examinations are not simply an 'external' factor but something that is visible and oriented to in classroom interaction).

In sum, although most champions of technology have aimed for fundamental changes of classroom practice, when we look at actual cases of the adoption of various technologies, we find that teachers have selected those that fit with their existing practices (Cuban, 2001). It thus may be more realistic - although (at least at first sight) less appealing - to consider how technologies can lead to incremental rather than revolutionary changes in classroom practices. So it may be time to renew our interest in the work of teachers in the analysis of collaborative learning activities. As Hammer (2002), in a critical review of Colella's (2002) study of a learning environment based on programmable badges, put it:

'How can technology help teachers teach?' That question sounds 'teachercentred' ('bad') rather than 'student-centred' ('good'), but with respect to the development of educational technology this is a false dichotomy. Colella is writing within a community that has a long history of developing wonderful 
technological tools, working toward the sort of engagement, participation, and learning evident in this chapter. But students do not generally engage, participate, and learn in these ways - and they did not here - without facilitation, support, and guidance by talented teachers. (p. 402)

Rather than only asking how technologies can help pupils to learn, we should perhaps also ask how technologies can help teachers to help pupils to learn.

\section{Acknowledgements}

I am most indebted to the two teachers and their pupils who helped me with this project by allowing me to spend an extensive period of time in their classrooms. Without their generosity this study could not have been conducted. I would also like to thank Jacqueline Eke, Tim Koschmann, Oskar Lindwall, and Douglas Macbeth for very helpful comments and criticisms on earlier versions of this paper. Part of this research was supported through a British Academy Postdoctoral Fellowship and a Simon Research Fellowship (funded through an endowment made to the University of Manchester). 


\section{Appendix: Interface}

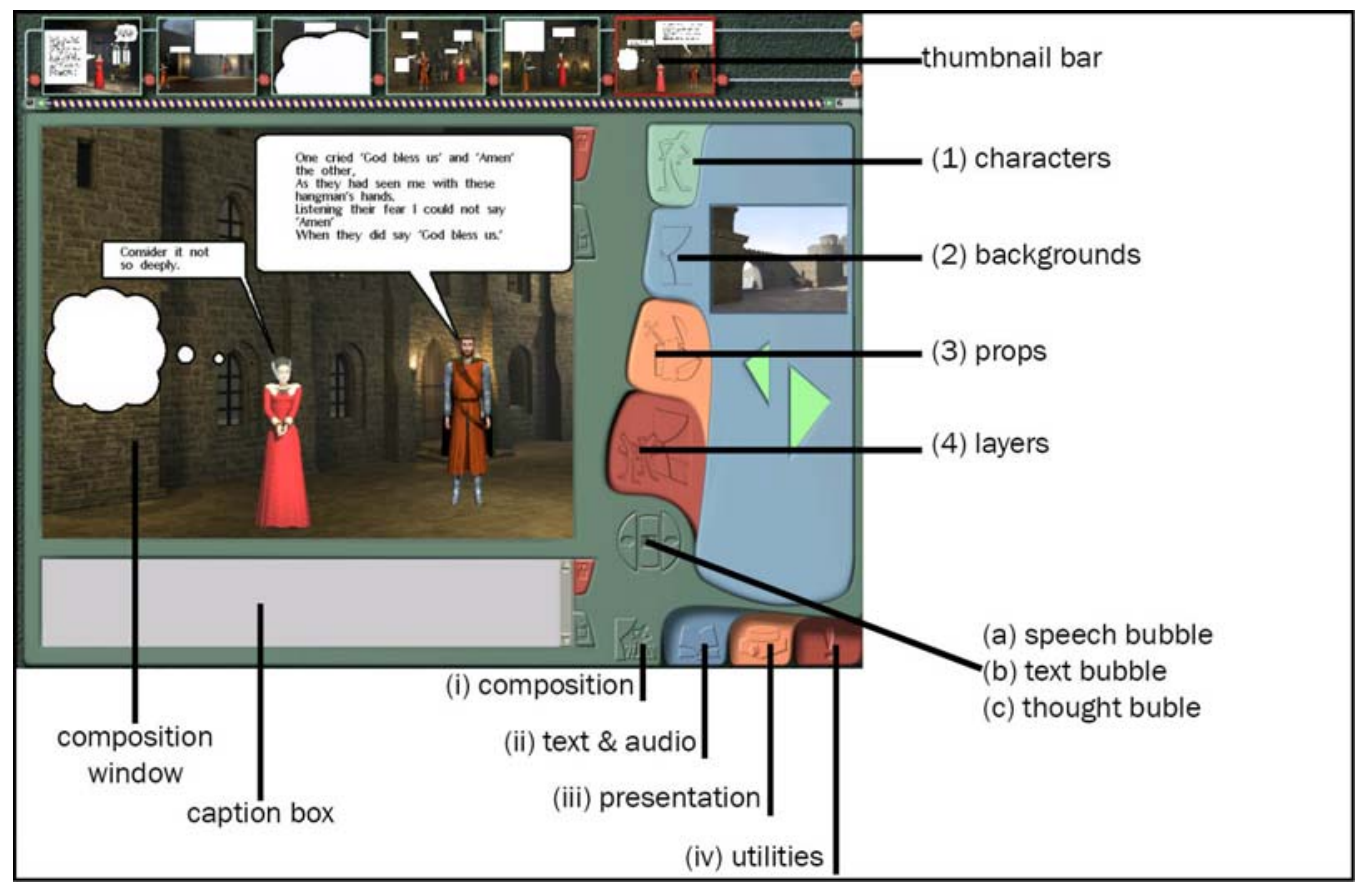

Greiffenhagen, C. Making rounds: the routine work of the teacher during collaborative learning with computers. Forthcoming in International Journal of Computer-Supported Collaborative Learning (ijCSCL). 
Page 48 of 52

\section{References}

Barnes, D. and F. Todd (1977). Communication and Learning in Small Groups. London: Routledge \& Kegan Paul.

Birmingham, P., C. Davies, and C. Greiffenhagen (2002). Turn to face the Bard: making sense of three-way interactions between teacher, pupils and technology in the classroom. Education, Communication \& Information 2 (2-3), 139-161.

Button, G. (Ed.) (1993). Technology in Working Order: Studies of Work, Interaction, and Technology. London: Routledge.

Button, G. and W. W. Sharrock (1996). Project work: the organisation of collaborative design and development in software engineering. Computer Supported Cooperative Work (CSCW) 5 (4), 369-386.

Çakir, M. P., A. Zemel, and G. Stahl (2009). The joint organization of interaction within a multimodal CSCL medium. International Journal of Computer-Supported Collaborative Learning 4 (2), 115-149.

Cazden, C., V. John, and D. Hymes (Eds.) (1972). Functions of Language in the Classroom. New York: Teachers College Press.

Chiu, M. M. (2004). Adapting teacher interventions to student needs during cooperative learning: how to improve student problem solving and time on-task. American Educational Research Journal 41 (2), 365-399.

Cohen, E. C. (1994 [1986]). Designing Groupwork: Strategies for the Heterogeneous Classroom (Second Ed.). New York: Teachers College Press.

Colella, V. (2002). Participatory simulations: building collaborative understanding through immersive dynamic modelling. In T. Koschmann, R. Hall, and N. Miyake (Eds.), CSCL2: Carrying Forward the Conversation, pp. 357-391. Mahwah, NJ: Lawrence Erlbaum.

Coulter, J. (2001). Human practices and the observability of the 'macro-social'. In T. R. Schatzki, K. Knorr-Cetina, and E. von Savigny (Eds.), The Practice Turn in Contemporary Theory, pp. 29-41. London: Routledge.

Cuban, L. (2001). Oversold and Underused: Computers in the Classroom. Cambridge, MA: Harvard University Press.

Dekker, R. and M. Elshout-Mohr (2004). Teacher interventions aimed at mathematical level raising during collaborative learning. Educational Studies in Mathematics 56 (1), 39-65.

Dillenbourg, P. (1999). Introduction: what do you mean by 'collaborative learning'? In P. Dillenbourg (Ed.), Collaborative Learning: Cognitive and Computational Approaches, pp. 119. Amsterdam: Pergamon.

Dillenbourg, P. (2008). Integrating technologies into educational ecosystems. Distance Education 29 (2), 127-140.

Dillenbourg, P. and P. Jermann (2010). Technology for classroom orchestration. In M. S. Khine and I. M. Saleh (Eds.), New Science of Learning: Cognition, Computers and Collaboration in Education, pp. 525-552. New York: Springer.

Ding, M., X. Li, D. Piccolo, and G. Kulm (2007). Teacher interventions in cooperative-learning mathematics classes. Journal of Educational Research 100 (3), 162-175.

Emerson, R. M. and M. Pollner (1976). Dirty work designations: their features and consequences in a psychiatric setting. Social Problems 23 (3), 243-254.

Greiffenhagen, C. Making rounds: the routine work of the teacher during collaborative learning with computers. Forthcoming in International Journal of Computer-Supported Collaborative Learning (ijCSCL). 
Ford, C. E. (1999). Collaborative construction of task activity: coordinating multiple resources in a high school physics lab. Research on Language and Social Interaction 32 (4), 369-408.

Garcia, A. C. and J. B. Jacobs (1999). The eyes of the beholder: understanding the turn-taking system in quasi-synchronous computer-mediated communication. Research on Language and Social Interaction 32 (4), 337-367.

Garfinkel, H. (1967). Studies in Ethnomethodology. Englewood Cliffs, NJ: Prentice-Hall.

Garfinkel, H. (2002). Ethnomethodology's Program: Working Out Durkheim's Aphorism. Lanham, MD: Rowman \& Littlefield.

Garfinkel, H. and H. Sacks (1970). On formal structures of practical action. In J. C. McKinney and E. A. Tiryakian (Eds.), Theoretical Sociology: Perspectives and Developments, pp. 338366. New York: Appleton-Century-Crofts.

Gibson, R. (1998). Teaching Shakespeare. Cambridge: Cambridge University Press.

Gillies, R. M. (2004). The effects of communication training on teachers' and students' verbal behaviours during cooperative learning. International Journal of Educational Research 41(3), 257-279.

Gillies, R. M., A. F. Ashman, and J. Terwel (Eds.) (2008). The Teacher's Role in Implementing Cooperative Learning in the Classroom. New York: Springer.

Glenn, P. J., T. Koschmann, and M. Conlee (1999). Theory presentation and assessment in a problem-based learning group. Discourse Processes 27 (2), 119-133.

Goodwin, C. (1994). Professional vision. American Anthropologist 96 (3), 606-633.

Greiffenhagen, C. (2008). Unpacking tasks: the fusion of new technology with instructional work. Computer Supported Cooperative Work (CSCW) 17 (1), 35-62.

Greiffenhagen, C. (forthcoming). Visual grammar in practice: negotiating the arrangement of speech bubbles in storyboards. Forthcoming in Semiotica.

Greiffenhagen, C. and W. Sharrock (2008). Where do the limits of experience lie? Abandoning the dualism of objectivity and subjectivity. History of the Human Sciences 21 (3), 70-93.

Greiffenhagen, C. and W. Sharrock (forthcoming). Does mathematics look certain in the front, but fallible in the back? Forthcoming in Social Studies of Science.

Greiffenhagen, C. and R. Watson (2009). Visual repairables: analysing the work of repair in human-computer interaction. Visual Communication 8 (1), 65-90.

Gumperz, J. and D. Hymes (Eds.) (1972). Directions in Sociolinguistics: The Ethnography of Communication. New York: Hold, Rinehart \& Winston.

Hammer, D. (2002). Powerful technology and powerful instruction. In T. Koschmann, R. Hall, and N. Miyake (Eds.), CSCL2: Carrying Forward the Conversation, pp. 399-403. Mahwah, NJ: Lawrence Erlbaum.

Heap, J. L. (1989a). Collaborative practices during word processing in a first grade classroom. In C. Emihovich (Ed.), Locating Learning: Ethnographic Perspectives on Classroom Research, pp. 263-288. Norwood, NJ: Ablex.

Heap, J. L. (1989b). Sociality and cognition in collaborative computer writing. In D. Bloome (Ed.), Classroom and Literacy, pp. 135-157. Norwood, NJ: Ablex.

Heath, C. and P. Luff (1992). Collaboration and control: crisis management and multimedia technology in London underground line control rooms. Computer Supported Cooperative Work (CSCW) 1 (1-2), 69-94. 
Heath, C., M. Jirotka, P. Luff, and J. Hindmarsh (1995). Unpacking collaboration: the interactional organisation of trading in a city dealing room. Computer Supported Cooperative Work (CSCW) 3 (2), 147-165.

Heath, C., J. Hindmarsh, and P. Luff (2010). Video in Qualitative Research: Analysing Social Interaction in Everyday Life. London: Sage.

Hertz-Lazarowitz, R. and H. Shachar (1990). Teachers' verbal behaviour in cooperative and whole-class instruction. In S. Sharan (Ed.), Cooperative Learning: Theory and Research, pp. 77-94. New York: Praeger.

Hughes, E. C. (1971). The Sociological Eye: Selected Papers. Chicago: Aldine.

Ivarsson, J. (2010). Developing the construction sight: architectural education and technological change. Visual Communication 9 (2), 171-191.

Johnson, D. W. and R. T. Johnson (1994 [1975]). Learning Together and Alone: Cooperative, Competitive, and Individualistic Learning (Fourth Ed.). Boston: Allyn and Bacon.

Karlsson, G. (2010). Animation and grammar in science education: learners' construal of animated educational software. International Journal of Computer-Supported Collaborative Learning 5 (2), 167-189.

Kelly, G., T. Crawford, and J. L. Green (2001). Common task and uncommon knowledge: dissenting voices in the discursive construction of physics across small laboratory groups. Linguistics and Education 12 (2), 135-174.

Koschmann, T. (Ed.) (1996). CSCL: Theory and Practice of an Emerging Paradigm. Hillsdale, NJ: Lawrence Erlbaum.

Koschmann, T. (1999). Computer support for collaboration and learning. Journal of the Learning Sciences 8 (3\&4), 495-497.

Koschmann, T., P. J. Glenn, and M. Conlee (2000). When is a problem-based tutorial not a tutorial? Analyzing the tutor's role in the emergence of a learning issue. In D. Evensen \& C. Hmelo (Eds.), Problem-based learning: A research perspective on learning interaction, pp. 53-74. Mahwah, NJ: Lawrence Erlbaum.

Koschmann, T., R. Hall, and N. Miyake (Eds.) (2002). CSCL 2: Carrying Forward the Conversation. Hillsdale, NJ: Lawrence Erlbaum.

Koschmann, T., G. Stahl, and A. Zemel (2007). The video analyst's manifesto (or the implications of Garfinkel's policies for studying instructional practice in design-based research). In R. Goldman, R. Pea, B. Barron, and S. J. Derry (Eds.), Video Research in the Learning Sciences, pp. 133-143. Mahwah, NJ: Lawrence Erlbaum.

Lindwall, O. and G. Lymer (2005). Vulgar competence, ethnomethodological indifference and curricular design. Proceedings of CSCL 2005 (Taipei, Taiwan, May 30 - June 4, 2005), pp. 388-397.

Lindwall, O. and G. Lymer (2008). The dark matter of lab work: illuminating the negation of disciplined perception in mechanics. Journal of the Learning Sciences 17 (2), 180-224.

Luff, P., J. Hindmarsh, and C. Heath (Eds.) (2000). Workplace Studies: Recovering Work Practice and Informing System Design. Cambridge: Cambridge University Press.

Lymer, G., J. Ivarsson, and O. Lindwall (2009). Contrasting the use of tools for presentation and critique: some cases from architectural education. International Journal of ComputerSupported Collaborative Learning 4 (4), 423-444.

Lynch, M. (1997 [1979]). Preliminary notes on judges' work: the judge as a constituent of courtroom 'hearings'. In M. Travers and J. F. Manzo (Eds.), Law in Action: 
Ethnomethodological and Conversation Analytic Approaches to Law, pp. 99-130. Aldershot: Dartmouth.

Macbeth, D. H. (1990). Classroom order as practical action: the making and un-making of a quiet reproach. British Journal of Sociology of Education 11 (2), 189-214.

Macbeth, D. H. (1991). Teacher authority as practical action. Linguistics and Education 3 (4), 281-313.

Macbeth, D. H. (1992). Classroom 'floors': material organizations as a course of affairs. Qualitative Sociology 15 (2), 123-150.

Macbeth, D. H. (2003). Hugh Mehan's Learning Lessons reconsidered: on the differences between the naturalistic and critical analysis of classroom discourse. American Educational Research Journal 40 (1), 239-280.

McDermott, R. P., K. Gospodinoff, and J. Aron (1978). Criteria for an ethnographically adequate description of concerted activities and their contexts. Semiotica 24 (3/4), 245-275.

McHoul, A. W. (1978). The organization of turns at formal talk in the classroom. Language in Society 7 (1), 183-213.

Mehan, H. (1979). Learning Lessons: Social Organization in the Classroom. Cambridge, MA: Harvard University Press.

Mehan, H. (1989). Microcomputers in classrooms: educational technology or social practice? Anthropology and Education Quarterly 20 (1), 4-22.

Mercer, N. and E. Fisher (1992). How do teachers help children to learn? an analysis of teachers' interventions in computer-based activities. Learning and Instruction 2 (4), 339-355.

O'Connor, M. C. and S. Michaels (1993). Aligning academic task and participation status through revoicing: analysis of a classroom discourse strategy. Anthropology and Education Quarterly 24 (4), 318-335.

Payne, G. C. F. (1976). Making a lesson happen: an ethnomethodological analysis. In M. Hammersley and P. Woods (Eds.), The Process of Schooling: A Sociological Reader, pp. 3340. London: Routledge.

Payne, G. C. F. and E. C. Cuff (Eds.) (1982). Doing Teaching: The Practical Management of Classrooms. London: Batsford.

Pea, R. D. (1996). Seeing what we build together: distributed multimedia learning environments for transformative communications. In T. Koschmann, T. (Ed.), CSCL: Theory and Practice of an Emerging Paradigm, pp. 171-186. Hillsdale, NJ: Lawrence Erlbaum.

Pea, R. D. (2004). The social and technological dimensions of scaffolding and related theoretical concepts for learning, education, and human activity. Journal of the Learning Sciences 13 (3), 423-451.

Roschelle, J. (1992). Learning by collaborating: convergent conceptual change. Journal of the Learning Sciences 2 (3), 235-276.

Roschelle, J. and S. D. Teasley (1995). The construction of shared knowledge in collaborative problem solving. In O’Malley, C. (Ed.), Computer Supported Collaborative Learning, pp. 69-97. Berlin: Springer.

Roth, W.-M. (1995). Affordances of computers in teacher-student interaction: the case of Interactive Physics. Journal of Research in Science Teaching 32 (4), 329-347.

Sacks, H. (1992). Lectures on Conversation (Edited by G. Jefferson). Oxford: Blackwell.

Schegloff, E. A. (1996). Confirming allusions: toward an empirical account of action. American Journal of Sociology 102 (1), 161-216. 
Schegloff, E. A. (2007). Sequence Organization in Interaction. Cambridge: Cambridge University Press.

Schenkein, J. (1978). Sketch of an analytic mentality for the study of conversational interaction. In J. Schenkein (Ed.), Studies in the Organization of Conversational Interaction, pp. 1-6. New York: Academic Press.

Sharrock, W. W. and R. J. Anderson (1994). The user as a scenic feature of the design space. Design Studies 15 (1), 5-18.

Sharrock, W. W. and D. R. Watson (1988). Autonomy among social theories: the incarnation of social structures. In N. G. Fielding (Ed.), Actions and Structure: Research Methods and Social Theory, pp. 56-77. London: Sage.

Sorensen, E. (2009). The Materiality of Learning: Technology and Knowledge in Educational Practice. Cambridge: Cambridge University Press.

Stahl, G. (2006). Group Cognition: Computer Support for Collaborative Knowledge Building. Cambridge, MA: MIT Press.

Stahl, G. (Ed.) (2009). Studying Virtual Math Teams. New York: Springer.

Suchman, L. A. (1987). Plans and Situated Actions: The Problem of Human-Machine Communication. Cambridge: Cambridge University Press.

Urhahne, D., S. Schanze, T. Bell, A. Mansfield, and J. Holmes (2010). Role of the teacher in computer-supported collaborative inquiry learning. International Journal of Science Education 32 (2), 221-243.

Watson, R. (2009). Analysing Practical and Professional Texts: A Naturalistic Approach. Farnham: Ashgate.

Webb, N. M., K. M. Nemer, and M. Ing (2006). Small-group reflections: parallels between teacher discourse and student behaviour in peer-directed groups. Journal of the Learning Sciences 15 (1), 63-119.

Webb, N. M., M. L. Franke, T. De, A. G. Chan, D. Freund, P. Shein, and D. K. Melkonian (2009). 'Explain to your partner': teachers' instructional practices and students' dialogue in small groups. Cambridge Journal of Education 39 (1), 49-70.

Zemel, A., T. Koschmann, C. LeBaron, and P. Feltovich (2008). 'What are we missing?' Usability’s indexical ground. Computer Supported Cooperative Work (CSCW) 17 (1), 63-85. 